九州大学学術情報リポジトリ

Kyushu University Institutional Repository

\title{
Mineralogical study of rhodonites in Japan, with special reference to contact metamorphism
}

Momoi, Hitoshi

Faculty of Science, Kyushu University

https://doi.org/10.5109/1543611

出版情報：九州大學理學部紀要：Series D, Geology. 15 (1)，pp.39-63，1964-06-25. Faculty of Science, Kyushu University バージョン：

権利関係 : 
Mem. Fac. Sci., Kyushu Univ., Ser. D, Geology, Vol. XV, No. 1, pp. 39-63, 17 text-figs. 4 tables, May 31, 1964

\title{
Mineralogical study of rhodonites in Japan, with special reference to contact metamorphism
}

\author{
By \\ Hitoshi MOMOI
}

\begin{abstract}
Sixteen rhodonites from Japan were chemically analyzed and examined by the $\mathrm{X}$-ray diffractometer. The chemical characteristics were discussed together with pyroxmangite in special referring to their calcium contents. The differences among angles of some powder reflections vary with the calcium contents of rhodonite. By the heating at $1000^{\circ} \mathrm{C}$ in air for 1 hour, the patterns of calcium-rich rhodonites become very similar to those of the calcium-poor rhodonites. The heated product at $1200^{\circ} \mathrm{C}$ in air for 1 hour being bustamite, also was discussed in comparison with some other manganese silicates. A large number of rhodonites from Japan examined by the X-ray powder method with the result that the specimens from the replacement ores are rich in calcium on the contrary that those from the contact metamorphic ores are poor. This differencies correlated to the contact metamorphism of the manganese ores.
\end{abstract}

\section{Introduction}

Rhodonite is an important ore mineral and occurs from a great number of manganese mines in Japan. The chemical and optical relationships of rhodonite and related minerals were discussed in detail by Sundius (1931) and TILLEY (1937), and the crystal structures were recently clarified by BURGER (1956) and LIEBAU et al. (1959). The synthetic experiments of these minerals were also made by many persons since the beginning of this century (recently MUAN, 1959; GLASSER and GLASSER, 1960). Between rhodonite and bustamite there is an immiscible gap as Sundius stated (1931), and the chemical distinction is clear. In 1955, LEE pointed out that some of the red metasilicate, which had been regarded as rhodonite, in Japanese manganese ores are structurally pyroxmangite, being nearly pure $\mathrm{MnSiO}_{3}$ and almost free from calcium and iron. The discovery of pyroxmangite calls for the mineralogical reexamination of rhodonites in Japan.

This paper firstly makes the refinement of the chemical and optical relationships between rhodonite and pyroxmangite, and secondary treats the prediction of the chemical composition of rhodonite by the X-ray powder patterns. Thirdly, the heating effects to rhodonite are examined and discussed in relation to contact metamorphism. Lastly, the characteristics of the Japanese rhodonites are discussed in some detail.

\footnotetext{
* Manuscript received October 31, 1963.
} 


\section{Chemical composition}

Many chemical data of rhodonites and pyroxmangites have been recorded, and chemical relationship of these minerals is rather well known. SunDIUs (1931) and Tilley (1937) thought that there was an immiscible gap between rhodonite and pyroxmangite, and that the pure $\mathrm{MnSiO}_{3}$ mineral was rhodonite. The discovery of red pyroxmangite in the "rhodonite" ore by LEE (1955) brought about, however, the necessity of reexamination of the chemical relation of "rhodonite." WatanABE and Kato (1960)* discussed this problem in detail, and concluded that rhodonite and pyroxmangite in nature do not show the same chemical composition. In this paper, the relations are confirmed, and some facts of interest are presented regarding calcium content of rhodonite.

Sixteen rhodonites, confirmed by X-ray, from the various manganese mines were newly analyzed. The analyzed materials were prepared mainly with hand picking under the magnifying glass, and the Frantz Isodynamic Separater was often used. In chemical analyses, the common gravimetric method was used

Table 1. Chemical compositions and optical properties of rhodonites

\begin{tabular}{|c|c|c|c|c|c|c|c|c|}
\hline Number & 48 & 49 & 50 & 51 & 52 & 53 & 54 & 55 \\
\hline Locality & Yanagaso & Yoshida & Bandai & Inotani & Hata & Chizu & Horigoshi & Taguchi \\
\hline Sp.gr. & 3.566 & 3.614 & 3.592 & 3.594 & 3.619 & 3.634 & 3.620 & 3.700 \\
\hline $\mathrm{SiO}_{2}$ & 45.58 & 46.27 & 45.40 & 45.85 & 44.47 & 43.00 & 44.78 & 44.42 \\
\hline $\mathrm{Al}_{2} \mathrm{O}_{3}$ & 0.71 & 0.99 & 0.43 & 0.33 & 1.11 & 2.14 & 0.32 & 0.82 \\
\hline $\mathrm{Fe}_{2} \mathrm{O}_{3}$ & 0.99 & 0.48 & 0.83 & 0.83 & 1.90 & 0.00 & 0.49 & 0.40 \\
\hline $\mathrm{FeO}$ & 1.78 & 0.30 & 3.09 & 3.18 & 5.57 & 2.23 & 2.18 & 1.52 \\
\hline $\mathrm{MnO}$ & 41.58 & 46.05 & 42.67 & 41.66 & 40.09 & 47.74 & 45.81 & 49.85 \\
\hline $\mathrm{MgO}$ & 2.41 & 0.43 & 2.10 & 2.77 & 1.76 & 0.14 & 0.14 & 0.53 \\
\hline $\mathrm{CaO}$ & 5.76 & 5.48 & 4.07 & 4.48 & 4.38 & 4.30 & 5.16 & 1.53 \\
\hline $\mathrm{H}_{2} \mathrm{O}^{+}$ & 0.27 & - & 0.51 & 0.23 & 0.52 & 0.33 & 0.29 & 0.44 \\
\hline $\mathrm{H}_{2} \mathrm{O}^{-}$ & 0.13 & - & 0.45 & 0.18 & 0.24 & 0.10 & 0.34 & 0.24 \\
\hline Total & 99.21 & $(100.00)$ & 99.55 & 99.51 & 100.44 & 99.98 & 99.51 & 99.85 \\
\hline $\mathrm{FeSiO}_{3}$ & 4.0 & 0.9 & 6.2 & 6.3 & 12.1 & 4.0 & 4.3 & 3.2 \\
\hline $\mathrm{MnSiO}_{3}$ & 75.1 & 84.9 & 77.7 & 74.8 & 72.3 & 85.8 & 83.4 & 91.6 \\
\hline $\mathrm{MgSiO}_{3}$ & 7.7 & 1.4 & 6.7 & 8.7 & 5.6 & 0.4 & 0.5 & 1.7 \\
\hline $\mathrm{CaSiO}_{3}$ & 13.2 & 12.8 & 9.4 & 10.2 & 10.0 & 9.8 & 11.8 & 3.5 \\
\hline$N x$ & 1.722 & - & - & - & 1.727 & - & - & 1.735 \\
\hline $\mathrm{Ny}$ & 1.726 & - & - & - & 1.731 & - & - & 1.740 \\
\hline $\mathrm{Nz}$ & 1.734 & - & - & - & 1.740 & - & - & 1.748 \\
\hline $\mathrm{Nz}-\mathrm{Nx}$ & 0.012 & - & - & - & 0.013 & - & - & 0.013 \\
\hline $2 \mathrm{Vz}$ & $71.5^{\circ}$ & - & - & - & $69.6^{\circ}$ & - & - & $61.0^{\circ}$ \\
\hline
\end{tabular}

* Read at the annual meeting of Mineralogical Society of Japan. 
Table 1. Chemical compositions and optical properties of rhodonites (Continued)

\begin{tabular}{|c|c|c|c|c|c|c|c|c|}
\hline Number & 56 & 57 & 58 & 59 & 60 & 61 & 63 & 64 \\
\hline Locality & Miyasugi & Renge & Zomeki & Akimoto & Tamaiwa & Kiura & Yamato & Hsihutsun \\
\hline Sp.gr. & 3.556 & 3.574 & 3.622 & 3.595 & 3.646 & 3.605 & 3.622 & 3.544 \\
\hline $\mathrm{SiO}_{2}$ & 46.38 & 45.95 & 43.98 & 45.23 & 45.17 & 44.01 & 43.02 & 46.50 \\
\hline $\mathrm{Al}_{2} \mathrm{O}_{3}$ & 0.00 & 0.85 & 0.93 & 0.51 & 0.85 & 0.95 & 0.23 & 0.62 \\
\hline $\mathrm{Fe}_{2} \mathrm{O}_{3}$ & 0.57 & 0.50 & 0.27 & 0.12 & 0.78 & 0.00 & 0.23 & n.d. \\
\hline $\mathrm{FeO}$ & 4.81 & 2.20 & 0.58 & 0.27 & 2.11 & 1.10 & 0.27 & 1.90 \\
\hline $\mathrm{MnO}$ & 39.52 & 43.58 & 49.17 & 47.16 & 47.20 & 46.64 & 45.49 & 41.42 \\
\hline $\mathrm{MgO}$ & 1.67 & 1.74 & 0.77 & 0.25 & 0.07 & 0.74 & 1.61 & 2.30 \\
\hline $\mathrm{CaO}$ & 6.35 & 5.63 & 2.58 & 5.14 & 3.59 & 3.42 & 5.23 & 6.62 \\
\hline $\mathrm{H}_{2} \mathrm{O}^{+}$ & 0.13 & 0.18 & 0.66 & 1.27 & 0.16 & 1.65 & 1.00 & 1.08 \\
\hline $\mathrm{H}_{2} \mathrm{O}^{-}$ & 0.22 & 0.27 & 0.22 & 0.29 & 0.16 & 0.01 & 0.35 & 0.14 \\
\hline Total & 99.65 & 99.82 & 99.16 & 100.24 & 100.09 & 99.66 & 100.72 & 100.79 \\
\hline $\mathrm{FeSiO}_{3}$ & 9.0 & 4.0 & 1.3 & 0.6 & 4.5 & 2.0 & 0.7 & 3.4 \\
\hline $\mathrm{MnSiO}_{3}$ & 71.2 & 77.9 & 90.2 & 86.6 & 86.9 & 87.4 & 82.2 & 74.4 \\
\hline $\mathrm{MgSiO}_{3}$ & 5.3 & 5.5 & 2.5 & 0.8 & 0.2 & 2.5 & 5.1 & 7.3 \\
\hline $\mathrm{CaSiO}_{3}$ & 14.5 & 12.7 & 6.0 & 12.0 & 8.4 & 8.1 & 12.0 & 15.0 \\
\hline $\mathrm{Nx}$ & 1.724 & 1.724 & 1.733 & 1.727 & - & 1.729 & 1.727 & 1.722 \\
\hline $\mathrm{Ny}$ & 1.728 & 1.728 & 1.736 & 1.730 & - & 1.733 & 1.730 & 1.725 \\
\hline $\mathrm{Nz}$ & 1.736 & 1.735 & 1.744 & 1.740 & - & 1.742 & 1.742 & 1.734 \\
\hline $\mathrm{Nz}-\mathrm{Nx}$ & 0.012 & 0.011 & 0.011 & 0.013 & - & 0.013 & 0.015 & 0.011 \\
\hline $2 \mathrm{Vz}$ & $70.4^{\circ}$ & $70.4^{\circ}$ & $68.5^{\circ}$ & $74.3^{\circ}$ & - & $68.3^{\circ}$ & $69.0^{\circ}$ & $64.0^{\circ}$ \\
\hline
\end{tabular}

Analyst: H. MoMor

along with the Volhard method for $\mathrm{Mn}_{3} \mathrm{O}_{4}$ and the redox titration for $\mathrm{FeO}$ and $\mathrm{CaO}$. The results are listed in Table 1 . The referred and newly analyzed data of rhodonite and pyroxmangite were calculated to know the pyroxene components, which were plotted in diagrams.

The variety and number of specimens used in this study may be enough to discuss the mineralogy of rhodonite as shown in Figures 1-4. The chemical compositions of rhodonites in these figures are convenient to discussed in focussing on the calcium content, because the calcium atom plays an important role in the formatoin of rhodonite structure.

The chemical differences of rhodonite and pyroxmangite can be presented as follows;

(1) In the diagrams of $\mathrm{MnSiO}_{3}-\mathrm{CaSiO}_{3}$ (Fig. 1) the variation of manganese component is more remarkable in pyroxmangite $\left(\mathrm{MnSiO}_{3} \quad 36-96\right.$ mol.\%) than in rhodonite $\left(\mathrm{MnSiO}_{3} 52-95 \mathrm{~mol} . \%\right)$. When both minerals having similar calcium content are compared, rhodonite is richer in manganese than pyroxmangite. In other words, the manganese contents decrease with increasing of calcium, and this tendency is more remarkable in pyrox- 


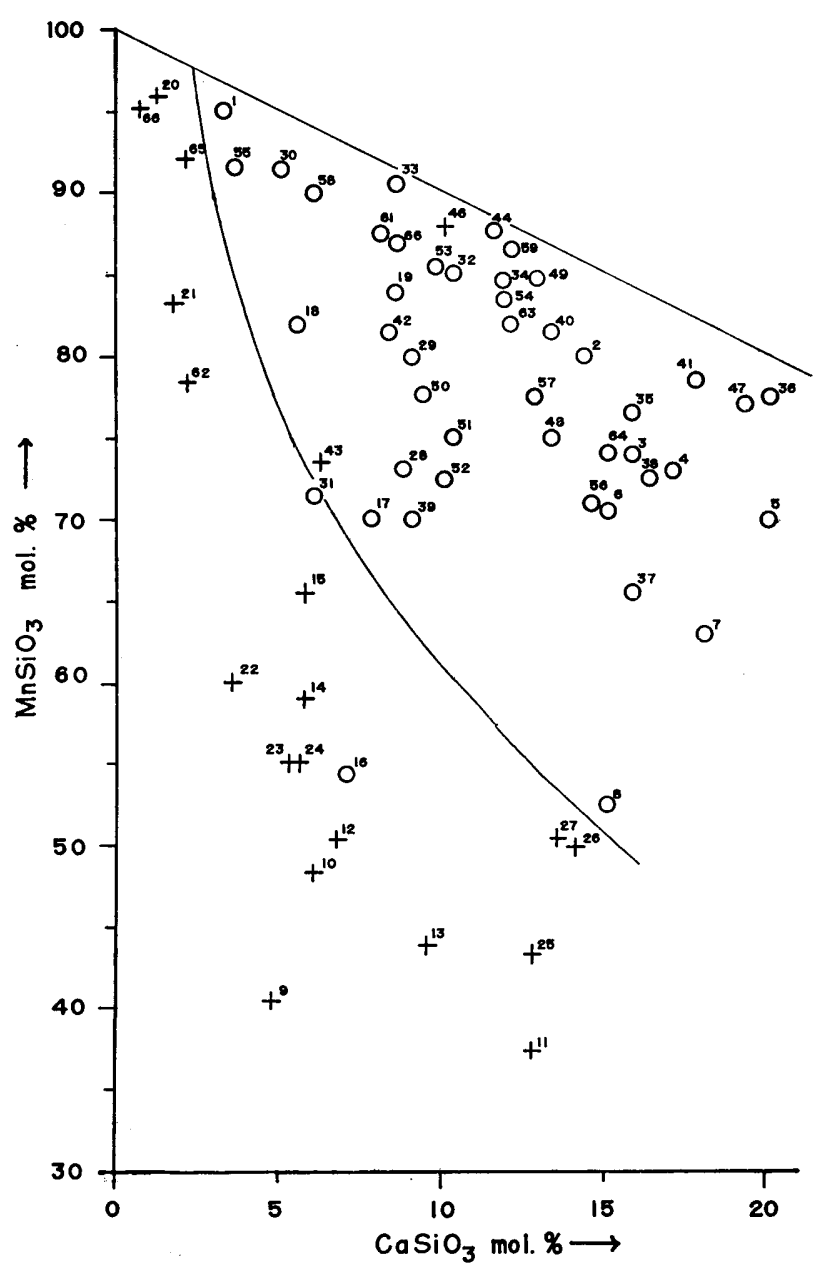

Fig. 1. Relation between $\mathrm{MnSiO}_{3}$ and $\mathrm{CaSiO}_{3}$ in rhodonites (open circles) and pyroxmangites (crosses).

mangite than in rhodonite. The plotted areas of the both minerals clearly differ from each other.

(2) In Figure 2, iron contents remarkably vary in pyroxmangite $\left(\mathrm{FeSiO}_{3}\right.$ 1-54 mol.\%). With increasing of calcium content, iron content in both minerals increases. This tendency is consipicuous in pyroxmangite.

(3) In Figure 3, magnesium content also increases with increasing of calcium content $\left(\mathrm{MgSiO}_{3} 0-15 \mathrm{~mol} . \%\right.$ in both materials). Although the division of the areas is not sharp, each minerals are densely plotted in the different parts : pyroxmangite contains more magnesium, and rhodonite more calcium.

(4) The diagram, $\mathrm{MnSiO}_{3}-\mathrm{FeSiO}_{3}-(\mathrm{Mg}, \mathrm{Ca}) \mathrm{SiO}_{3}$ (Fig. 4), is incompetent to get the information of the relation between rhodonite and pyroxmangite. This diagram, however, is convenient to present the relation between chemi- 


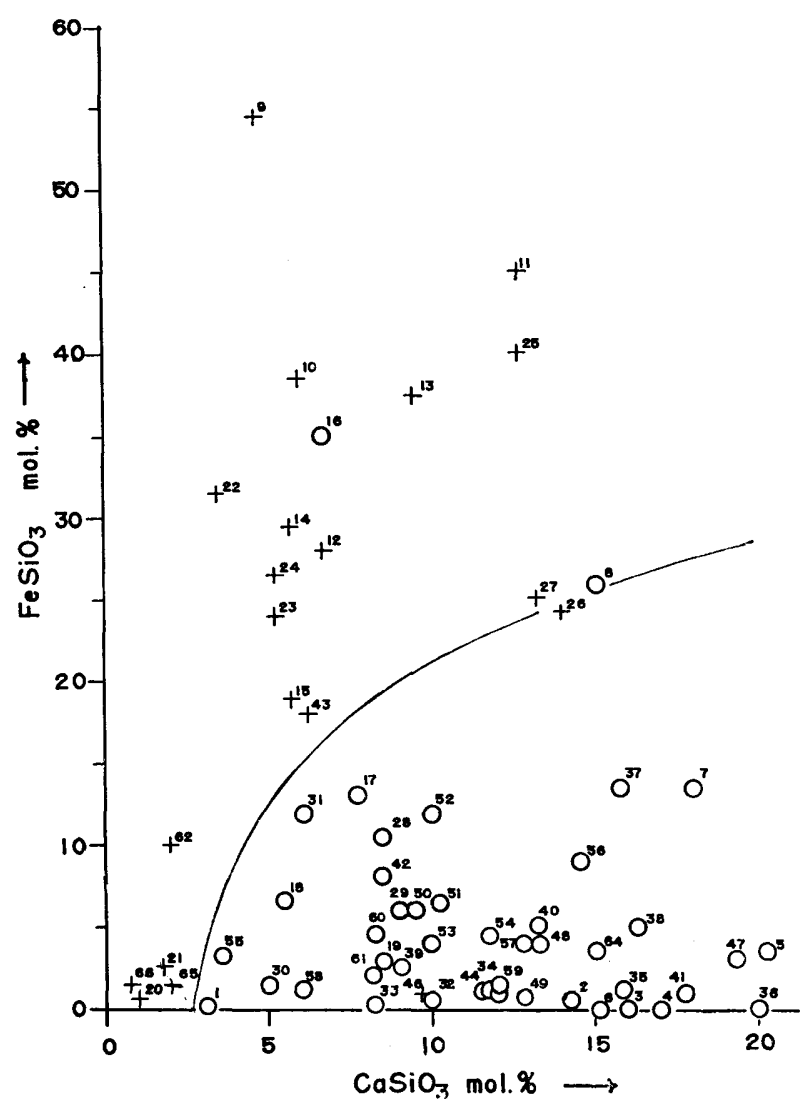

Fig. 2. Relation between $\mathrm{FeSiO}_{3}$ and $\mathrm{CaSiO}_{3}$ in rhodonites (open circles) and pyroxmangites (crosses).

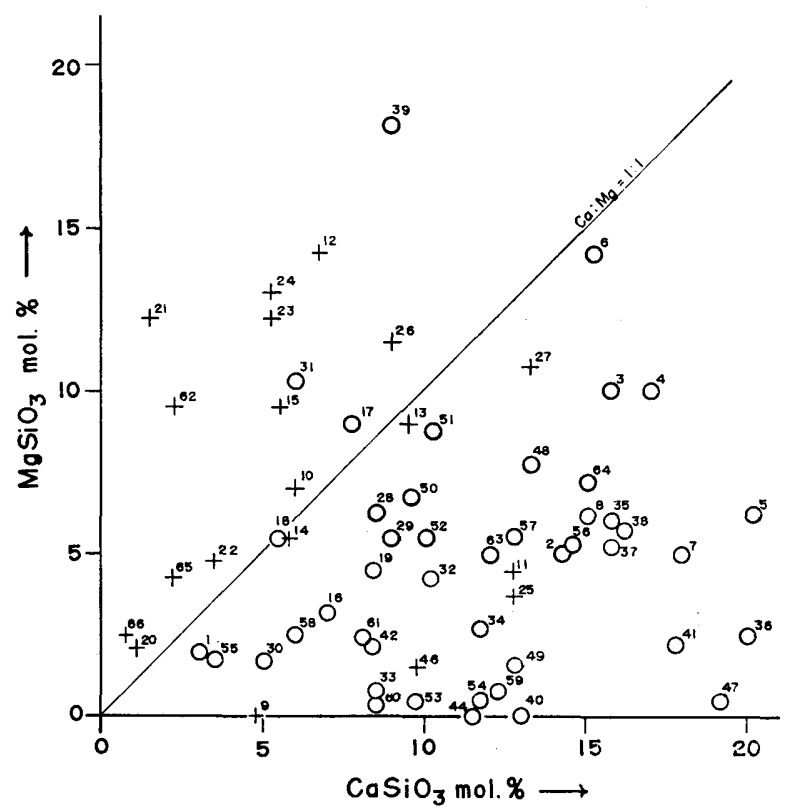

Fig. 3. Relation between $\mathrm{MgSiO}_{3}$ and $\mathrm{CaSiO}_{3}$ in rhodonites (open circles) and pyroxmangites (crosses). 


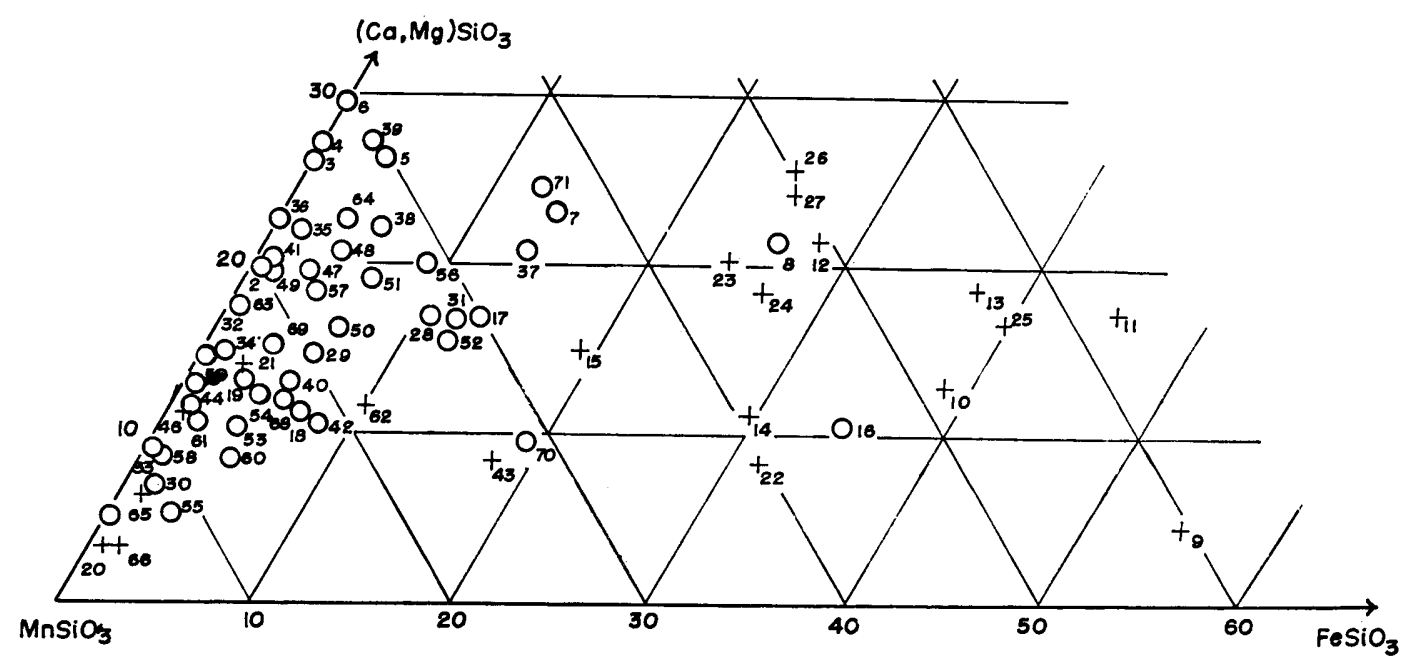

Fig. 4. $\mathrm{MnSiO}_{3}-(\mathrm{Ca}, \mathrm{Mg}) \mathrm{SiO}_{3}-\mathrm{FeSiO}_{3}$ diagram for rhodonites (open circles) and pyroxmangites (crosses).

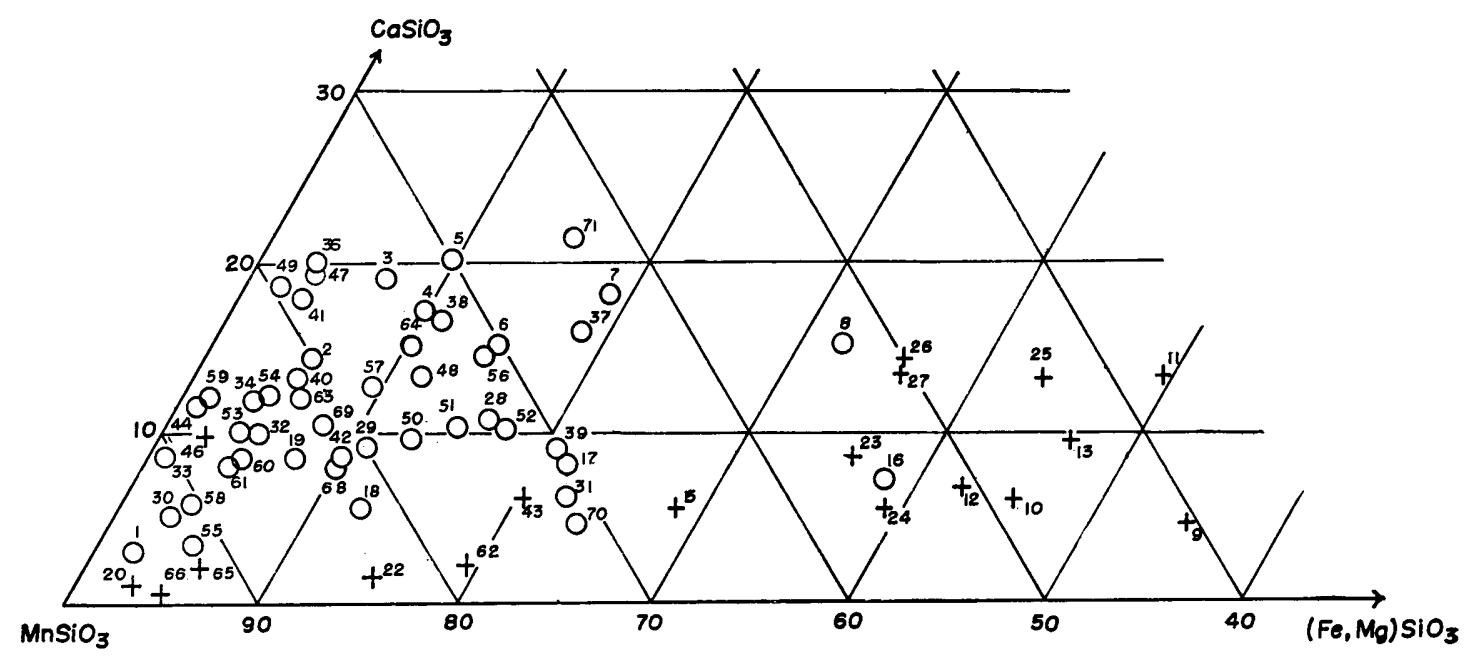

Fig. 5. $\mathrm{MnSiO}_{3}-\mathrm{CaSiO}_{3}-(\mathrm{Fe}, \mathrm{Mg}) \mathrm{SiO}_{3}$ diagram for rhodonites (open circles) and pyroxmangites (crosses).

cal composition and optical properties.

(5) In the diagram, $\mathrm{MnSiO}_{3}-\mathrm{CaSiO}_{3}-(\mathrm{Fe}, \mathrm{Mg}) \mathrm{SiO}_{3}$ (Fig. 5), the chemical characteristics of both minerals are distinct. Rhodonite is plotted in the area comparatively rich in calcium and pyroxmangites are in the area rich in iron.

An important problem is whether the dimorphism exists or not between rhodonite and pyroxmangite. GLASSER (1958) indicated the the synthetic $\mathrm{MnSiO}_{3}$ was identical with natural rhodonite by the X-ray powder pattern and optical properties. But, one or more inversions probably occurred at about $1200^{\circ} \mathrm{C}$ were not confirmed in his investigation. LIEBAU et al. (1958) found the 
three modifications of $\mathrm{MnSiO}_{3}: \alpha-, \beta$-, and $\gamma$-forms were structurally correlated with $\alpha$-wollastonite, $\beta$-wollastonite (bustamite), and rhodonite by the X-ray single crystal method. Since in nature there is pyroxmangite with nearly pure $\mathrm{MnSiO}_{3}$ should have another modification with pyroxmangite structure. It is probable that there exists dimorphism between rhodonite and pyroxmangite.

\section{Optical properties}

Optical data were obtained by the immersion method and the universal stage. The results are listed in Table 1, and also plotted in the diagrams showing the relation to the chemical compositions together with referred data (Figs. 6 and 7 ).

The relations between optical properties and chemical compositions of rhodo-

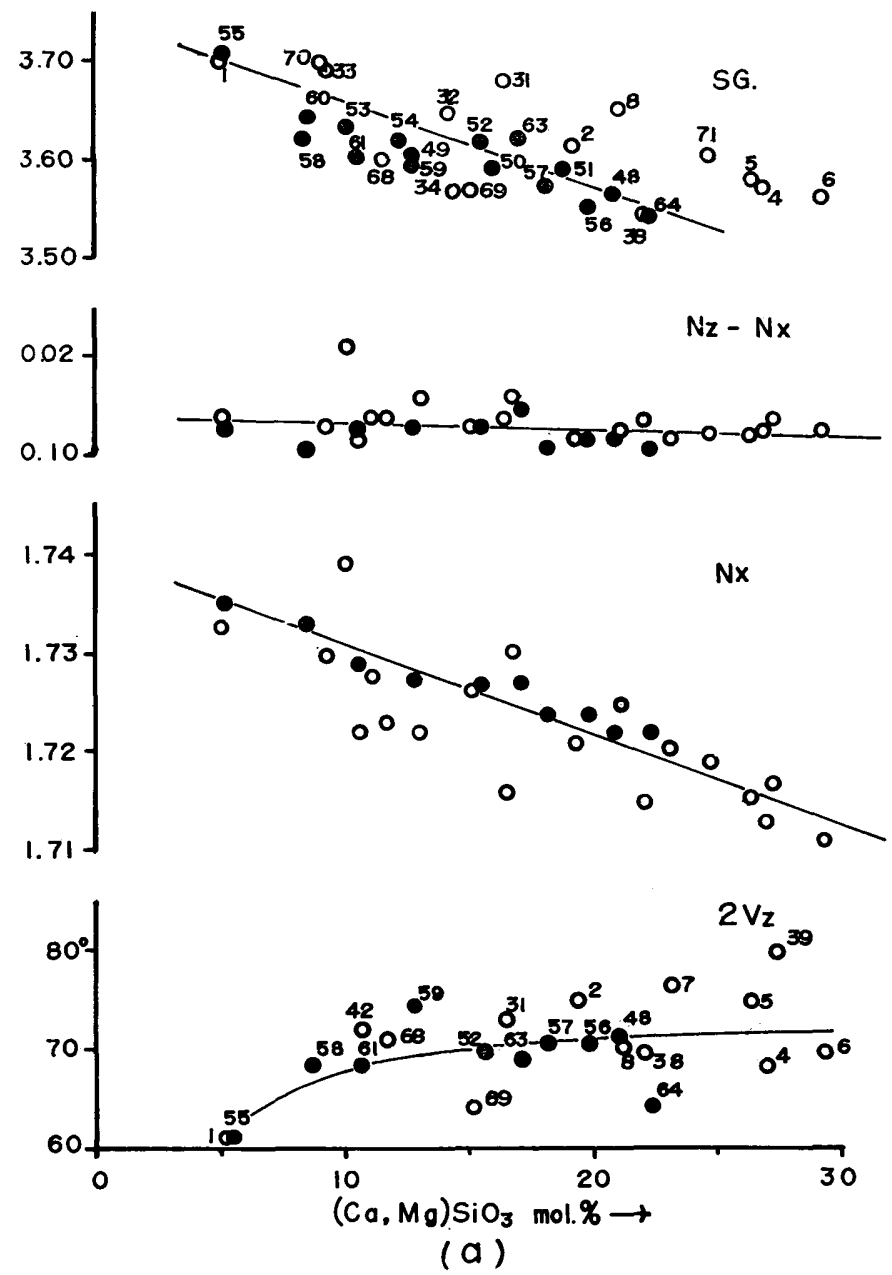

Fig. 6. Relation of optical properties and specific gravities to chemical composition. (a) Rhodonite. 

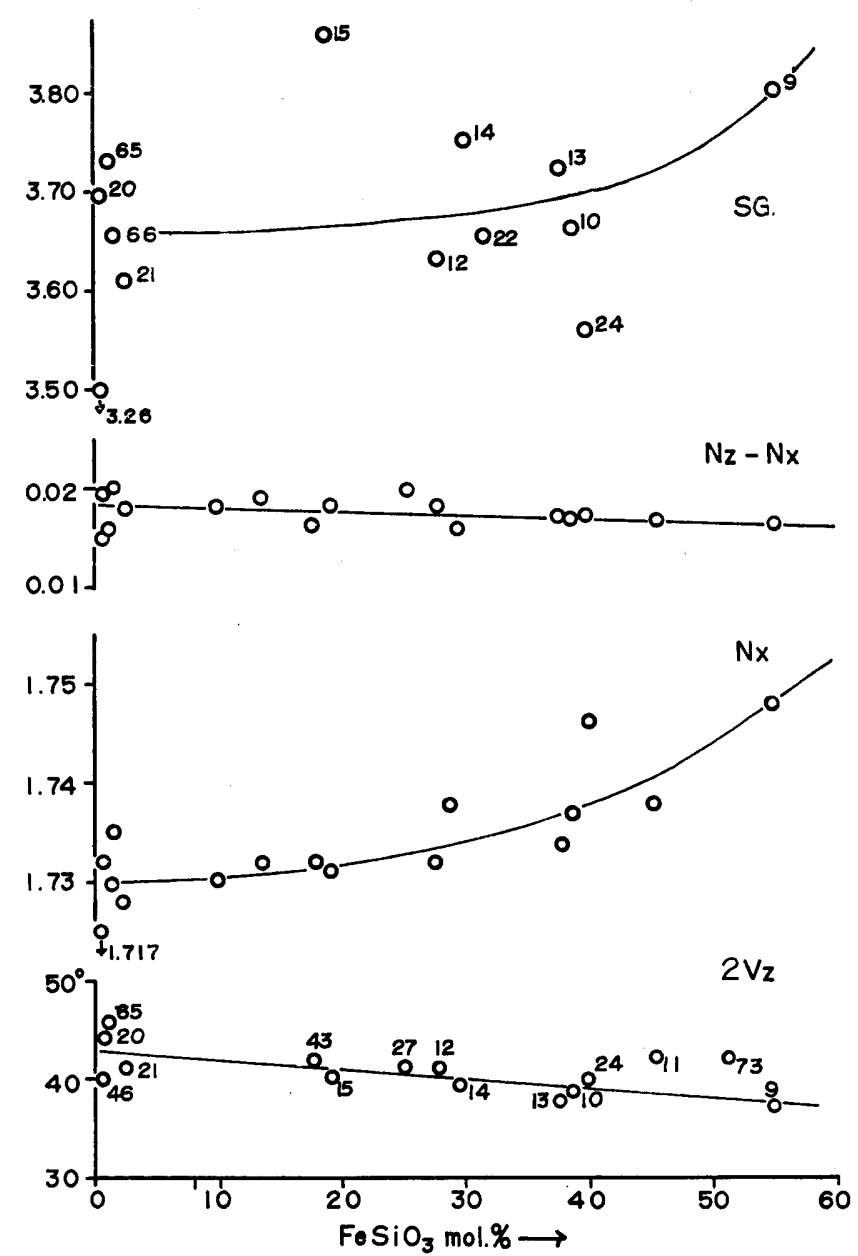

(b)

Fig. 6. Relation of optical properties and specific gravities to chemical composition. (b) Pyroxmangite

nites have been reported by some persons: HEY (1929), Sundius (1931), HIETANEN (1936), and TILLEY (1937). With increasing of calcium and magnesium contents, the refractive indices of rhodonites become lower (Fig. 6a). The refractive indices of pyroxmangites are known to become higher with increasing of iron contents (Fig. 6b). The differences between rhodonites and pyroxmangites are distinct on the double refractions and the optical axial angles: double refractions $(\mathrm{Nz}-\mathrm{Nx})$ of pyroxmangites are larger $(0.015-0.020)$ than those of rhodonites $(0.011-0.016)$, and optic axial angles of rhodonites $\left(61-80^{\circ}\right)$ are larger than those of pyroxmangites $\left(37-46^{\circ}\right)$. Some studies show that the refracitve indices of pyroxmangites are higher than those of rhodonites. The comparisons are, however, made among the minerals with different chemical composition, and when rhodonite and iron-poor pyroxmangite were compared, 

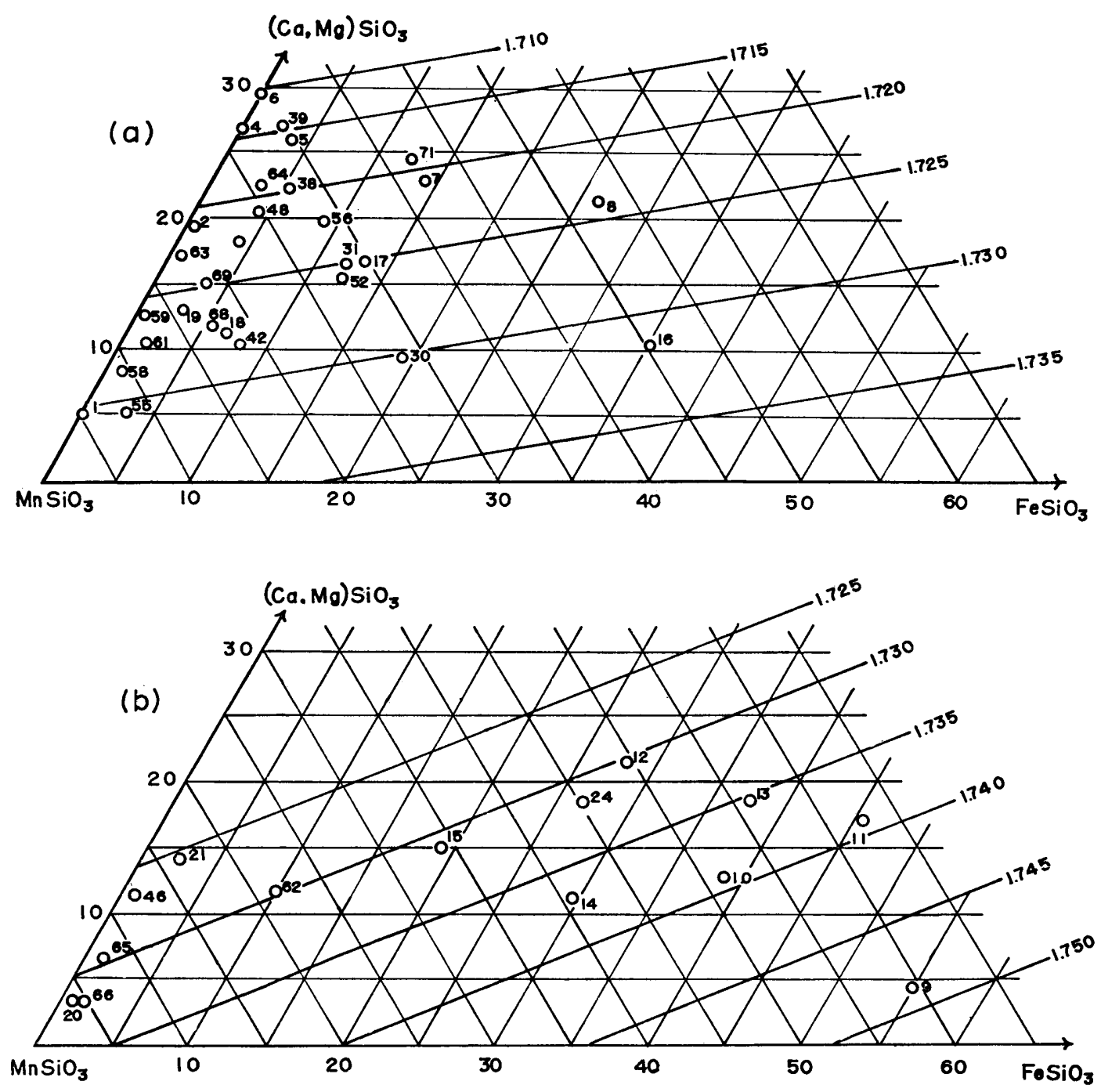

Fig. 7. Relation of refractive index $(\mathrm{Nx})$ to chemical composition in $\mathrm{MnSiO}_{3}-(\mathrm{Ca}, \mathrm{Mg}) \mathrm{SiO}_{3}-\mathrm{FeSiO}_{3}$ diagram. (a) Rhodonite. (b) Pyroxmangite.

no striking differences may be observable on the refractive indices (Figs. 7a and $b$ ).

It is known that rhodonite and pyroxmangite often show twinning on (010) in the Sundius's orientation. Most pyroxmangites in Japan have the twinning, but rhodonites have only rarely. Rhodonites in the metamorphic ores show sometimes waving extinction, and also twinning. The twinned flakes are in contact with an irregular boundary near to (010), and the angle between each optical planes is $5-10^{\circ}$. In pyroxmangite, the composite plane is flat and shows a sharp boundary in section. The angle between each optical planes is $65-70^{\circ}$. In a section of rhodonite nearly parallel to optical plane, one flake looked like a 
Table 2. Unit cell dimensions of pyroxmangite, rhodonite, bustamite, and wollastonite

\begin{tabular}{c|c|c|c|c}
\hline Mineral & Pyroxmangite & Rhodonite & Bustamite & Wollastonite \\
\hline a $(\AA)$ & 6.671 & 6.68 & $2 \times 6.912$ & 7.07 \\
b $(\AA)$ & 7.557 & 7.66 & $2 \times 7.706$ & 7.94 \\
c $(\AA)$ & 17.45 & 12.20 & 7.157 & 7.32 \\
$\alpha$ & $113^{\circ} 54^{\prime}$ & $111^{\circ} 54^{\prime}$ & $102^{\circ} 56^{\prime}$ & $103^{\circ} 26^{\prime}$ \\
$\beta$ & $84^{\circ}$ & $86^{\circ}$ & $89^{\circ} 29^{\prime}$ & $90^{\circ} 02^{\prime}$ \\
$\gamma$ & $94^{\circ} 18^{\prime}$ & $93^{\circ} 12^{\prime}$ & $94^{\circ} 51^{\prime}$ & $95^{\circ} 22^{\prime}$ \\
\hline \multirow{2}{*}{ Reference } & LIEBAU (1959) & LIEBAU et. al. & PEACOR \& & BUERGER \& \\
& & $(1959)$ & BUERGER (1962) & PREWITT (1961)
\end{tabular}
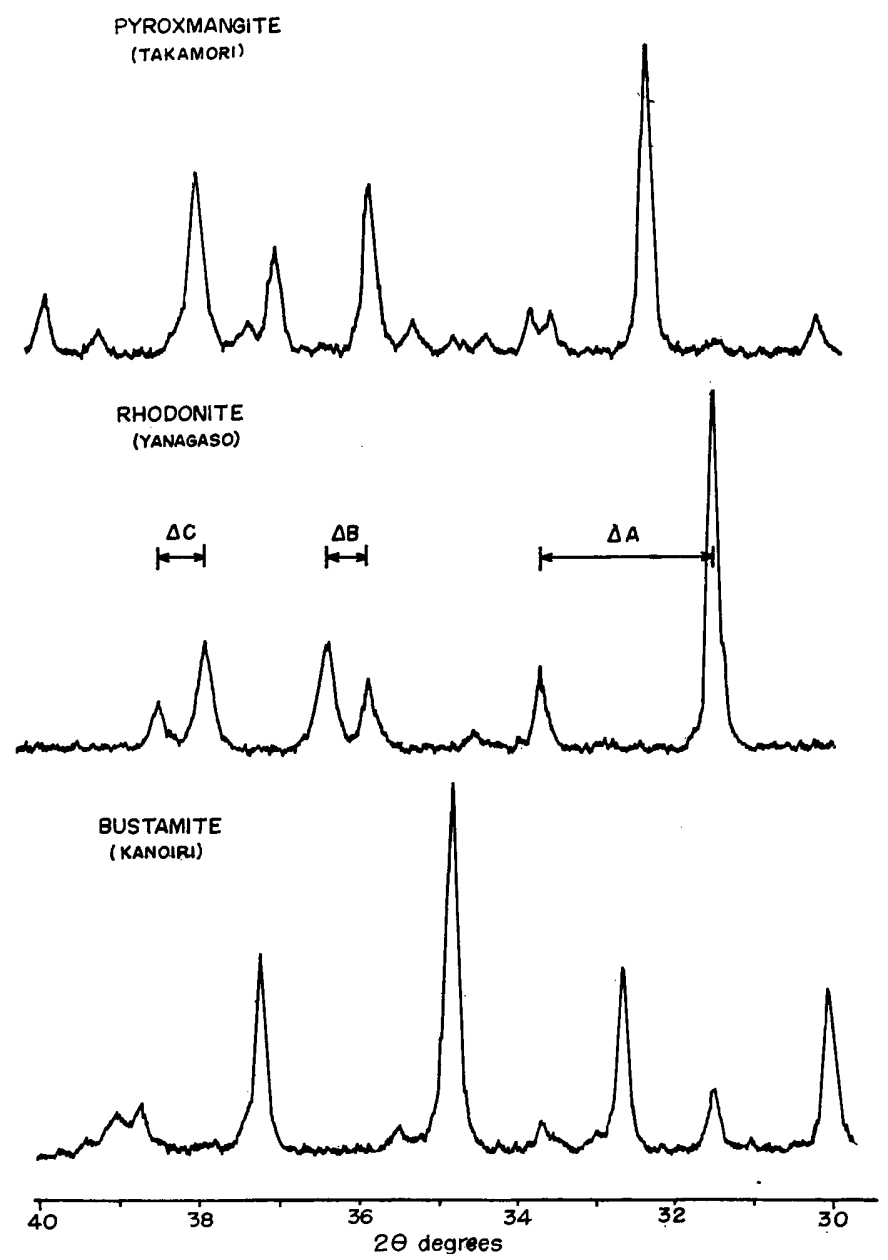

Fig. 8. X-ray diffraction patterns between $30^{\circ}$ and $40^{\circ}$ in $2 \theta$ (Fe $\mathrm{K} \alpha$ ) of pyroxmangite, rhodonite, and bustamite 


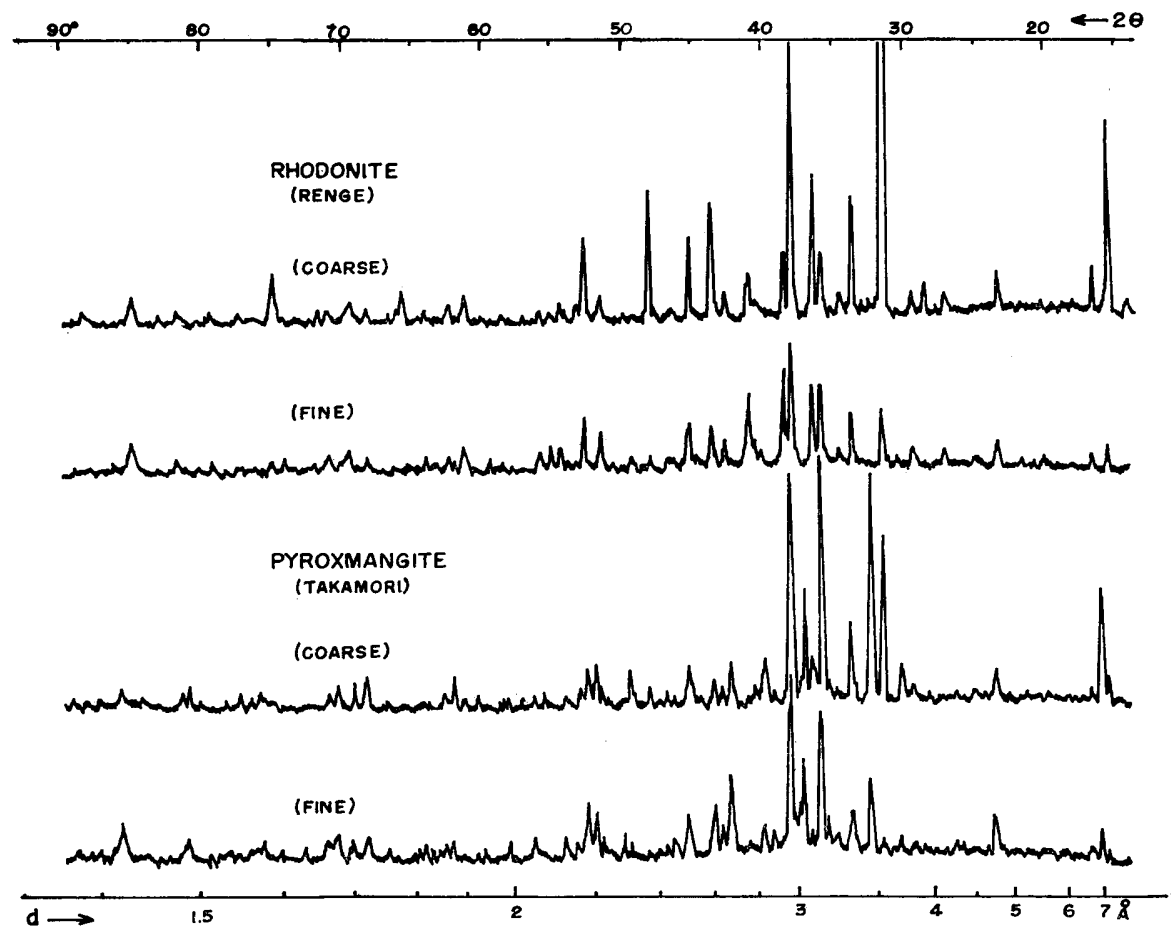

Fig. 9. Effect of grain size to X-ray diffraction patterns of rhodonite and pyroxmangite.

patch in the other flake owing to their slightly different double refractions.

\section{X-ray pattern}

Crystal structures of rhodonite and pyroxmangite were determined by LIEBAU et al. (1959) with results that rhodonite is constructed by the unit chain of five $\mathrm{SiO}_{4}$ tetrahedra and $\mathrm{Ca}$ atom exists by middle of the chain, "Nase," and pyroxmangite has seven $\mathrm{SiO}_{4}$ tetrahedra in the unit chain. The structure of bustamite was studied by BUERGER (1956) together with wollastonite and pectolite, and butamite was regarded as a double salt of $\mathrm{MnSiO}_{3}$ and $\mathrm{CaSiO}_{3}$. It was also concluded that the lengths of $\mathrm{a}_{0}$ and $\mathrm{c}_{0}$ axes are twice those of previous studies. The cell dimensions are listed in Table 2. These cell dimensions show a regular tendency with the variation of calcium content. The $a_{0}, b_{0}$ and $\beta$ of these minerals decrease from wollastonite to pyroxmangite. It seems to be related with the ratio of the manganese and calcium contents in crystals. X-ray powder data for these minerals are reported also by some authors (LEE, 1955; HUTTON, 1956; LIEBAU et al., 1958).

The present experiments were made in the following conditions: apparatus Shimadzu X-ray diffractometer, target $\mathrm{Fe}$, filter $\mathrm{Mn}, 30 \mathrm{KV}, 10 \mathrm{~mA}$, scanning speed $\frac{1}{2}-\frac{1}{4}$ degree per minute, chart speed $10 \mathrm{~mm}$ per minute, full scale 500 counts 
Table 3. Partial X-ray powder data for the natural and heated rhodonites

( $\mathrm{Fe} \mathrm{K} \alpha$ radiation)

\begin{tabular}{|c|c|c|c|c|c|c|}
\hline \multirow{2}{*}{ No. } & \multirow{2}{*}{ Locality } & \multicolumn{2}{|c|}{ Diff raction angle } & \multicolumn{3}{|c|}{ Differences in diffraction angles } \\
\hline & & $(020)$ & $(200)$ & $\Delta \mathrm{A}$ & $\Delta \mathrm{B}$ & $\Delta \mathrm{C}$ \\
\hline 48 & Yanagaso & $\begin{array}{l}31.54^{*} \\
31.54^{*}\end{array}$ & $\begin{array}{l}33.76 \\
33.72\end{array}$ & $\begin{array}{l}2.22 \\
2.18\end{array}$ & $\begin{array}{l}0.54 \\
0.60\end{array}$ & $\begin{array}{l}0.58 \\
0.54\end{array}$ \\
\hline 49 & Yoshida & $\begin{array}{l}31.50 \\
31.42\end{array}$ & $\begin{array}{l}33.71 \\
33.61\end{array}$ & $\begin{array}{l}2.21 \\
2.19\end{array}$ & $\begin{array}{l}0.53 \\
0.58\end{array}$ & $\begin{array}{l}0.58 \\
0.52\end{array}$ \\
\hline 50 & Bandai & $\begin{array}{l}31.62 \\
31.60\end{array}$ & $\begin{array}{l}33.78 \\
33.72\end{array}$ & $\begin{array}{l}2.16 \\
2.12\end{array}$ & $\begin{array}{l}0.62 \\
0.67\end{array}$ & $\begin{array}{l}0.49 \\
0.47\end{array}$ \\
\hline 51 & Inotani & $\begin{array}{l}31.63 \\
31.59\end{array}$ & $\begin{array}{l}33.79 \\
33.72\end{array}$ & $\begin{array}{l}2.16 \\
2.13\end{array}$ & $\begin{array}{l}0.65 \\
0.67\end{array}$ & $\begin{array}{l}0.51 \\
0.49\end{array}$ \\
\hline 52 & Hata & $\begin{array}{l}31.65 \\
31.56\end{array}$ & $\begin{array}{l}33.85 \\
33.72\end{array}$ & $\begin{array}{l}2.20 \\
2.16\end{array}$ & $\begin{array}{l}0.61 \\
0.69\end{array}$ & $\begin{array}{l}0.48 \\
0.48\end{array}$ \\
\hline 53 & Chizu & $\begin{array}{l}31.55 \\
31.53\end{array}$ & $\begin{array}{l}33.71 \\
33.68\end{array}$ & $\begin{array}{l}2.16 \\
2.15\end{array}$ & $\begin{array}{l}0.62 \\
0.66\end{array}$ & $\begin{array}{l}0.46 \\
0.45\end{array}$ \\
\hline 54 & Horigoshi & $\begin{array}{l}31.53 \\
31.49\end{array}$ & $\begin{array}{l}33.72 \\
33.66\end{array}$ & $\begin{array}{l}2.19 \\
2.17\end{array}$ & $\begin{array}{l}0.59 \\
0.64\end{array}$ & $\begin{array}{l}0.53 \\
0.47\end{array}$ \\
\hline 55 & Taguchi & $\begin{array}{l}31.70 \\
31.68\end{array}$ & $\begin{array}{l}33.79 \\
33.78\end{array}$ & $\begin{array}{l}2.09 \\
2.10\end{array}$ & $\begin{array}{l}0.76 \\
0.76\end{array}$ & $\begin{array}{l}0.37 \\
0.37\end{array}$ \\
\hline 56 & Miyasugi & $\begin{array}{l}31.52 \\
31.47\end{array}$ & $\begin{array}{l}33.77 \\
33.67\end{array}$ & $\begin{array}{l}2.25 \\
2.20\end{array}$ & $\begin{array}{l}0.54 \\
0.61\end{array}$ & $\begin{array}{l}0.58 \\
0.57\end{array}$ \\
\hline 57 & Renge & $\begin{array}{l}31.58 \\
31.57\end{array}$ & $\begin{array}{l}33.77 \\
33.72\end{array}$ & $\begin{array}{l}2.21 \\
2.15\end{array}$ & $\begin{array}{l}0.59 \\
0.63\end{array}$ & $\begin{array}{l}0.57 \\
0.55\end{array}$ \\
\hline 58 & Zomeki & $\begin{array}{l}31.61 \\
31.58\end{array}$ & $\begin{array}{l}33.73 \\
33.71\end{array}$ & $\begin{array}{l}2.13 \\
2.13\end{array}$ & $\begin{array}{l}0.69 \\
0.69\end{array}$ & $\begin{array}{l}0.44 \\
0.43\end{array}$ \\
\hline 59 & Akimoto & $\begin{array}{l}31.47 \\
31.46\end{array}$ & $\begin{array}{l}33.68 \\
33.62\end{array}$ & $\begin{array}{l}2.21 \\
2.16\end{array}$ & $\begin{array}{l}0.57 \\
0.68\end{array}$ & $\begin{array}{l}0.55 \\
0.50\end{array}$ \\
\hline 60 & Tamaiwa & $\begin{array}{l}31.55 \\
31.53\end{array}$ & $\begin{array}{l}33.73 \\
33.67\end{array}$ & $\begin{array}{l}2.18 \\
2.14\end{array}$ & $\begin{array}{l}0.63 \\
0.67\end{array}$ & $\begin{array}{l}0.47 \\
0.44\end{array}$ \\
\hline 61 & Kiura & $\begin{array}{l}31.57 \\
31.57\end{array}$ & $\begin{array}{l}33.72 \\
33.70\end{array}$ & $\begin{array}{l}2.15 \\
2.13\end{array}$ & $\begin{array}{l}0.67 \\
0.68\end{array}$ & $\begin{array}{l}0.46 \\
0.45\end{array}$ \\
\hline 63 & Yamato & $\begin{array}{l}31.51 \\
31.51\end{array}$ & $\begin{array}{l}33.69 \\
33.66\end{array}$ & $\begin{array}{l}2.18 \\
2.15\end{array}$ & $\begin{array}{l}0.59 \\
0.67\end{array}$ & $\begin{array}{l}0.54 \\
0.46\end{array}$ \\
\hline 64 & Hsihutsun & $\begin{array}{l}31.50 \\
31.47\end{array}$ & $\begin{array}{l}33.74 \\
33.66\end{array}$ & $\begin{array}{l}2.24 \\
2.19\end{array}$ & $\begin{array}{l}0.53 \\
0.60\end{array}$ & $\begin{array}{l}0.62 \\
0.56\end{array}$ \\
\hline
\end{tabular}

* Upper part for natural rhodonite, and lower part for heated one.

per second, time constant 5 seconds, slits $3-2-0.4 \mathrm{~mm}$, internal standard silicon, wave length $\mathrm{Fe} \mathrm{K} a \lambda=1.9373 \AA$.

The differences among powder patterns of rhodonite, pyroxmangite, and bustamite are distinct as shown in Figure 8. The grain size of powdered sample has effects on the preferred orientation parallel to the cleavages. Coarse grains bring about a reversal of the order of three strong reflections in pyroxmangite, i.e., $d=3.47 \AA, 3.14 \AA$, and $2.96 \AA$. This is also observed on the pattern of rhodonite. Particularly the reflection at $d=3.57 \AA$ of pyroxmangite is striking (Fig. 9) : that of coarse-grained sample is unreasonably strong.

The relations of powder pattern to chemical composition of rhodonites were investigated. To compare the powder patterns, six distinct reflections at $d=3.56$, $3.34,3.14,3.09,2.97$, and $2.93 \AA$ were selected, and the differences between 


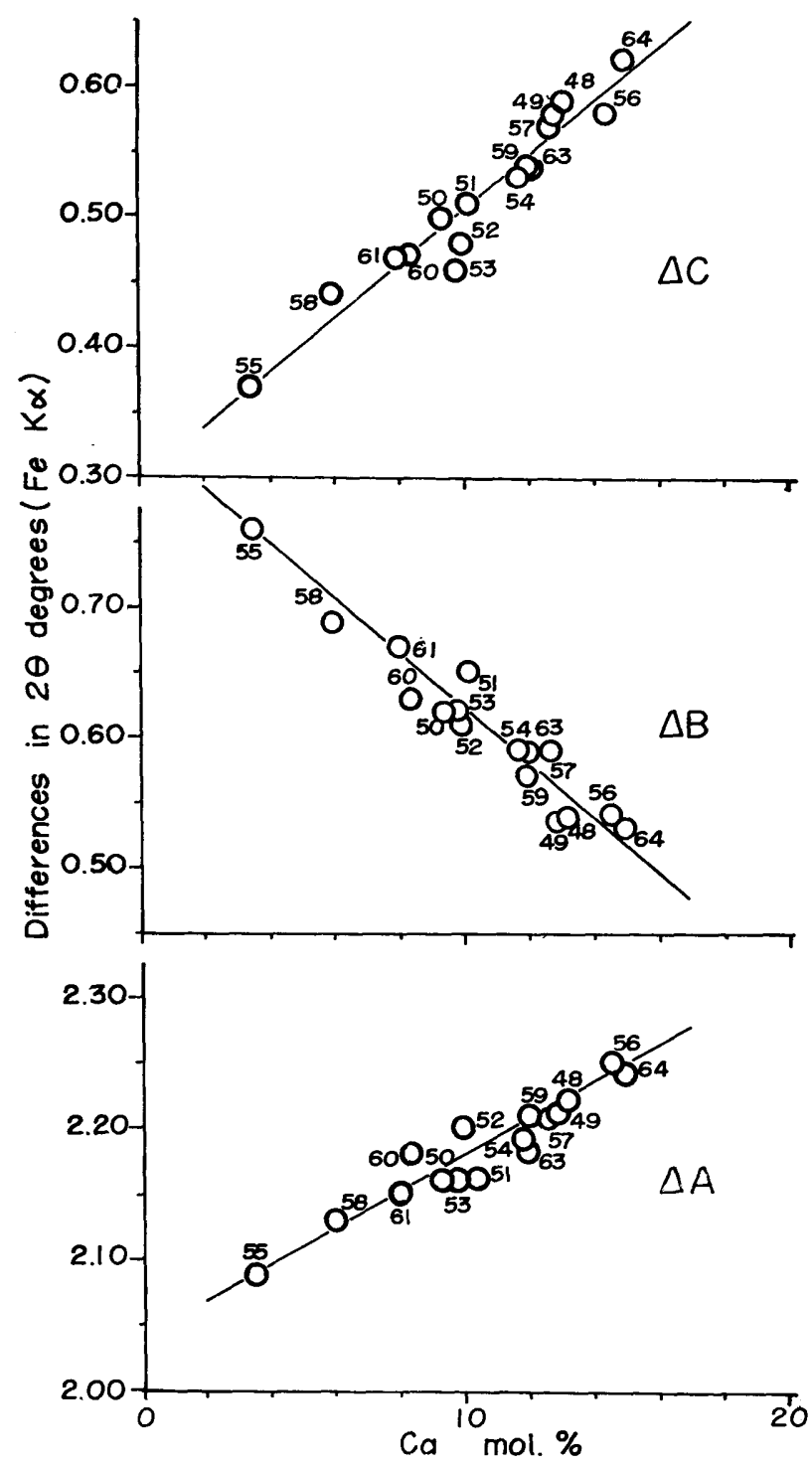

Fig. 10. Relation between calcium content and the differences $\Delta \mathrm{A}, \Delta \mathrm{B}$, and $\Delta \mathrm{C}$ in rhodonite.

reflection angles $(\Delta \mathrm{A}, \Delta \mathrm{B}$, and $\Delta \mathrm{C})$ were measured as shown in Figure 8 . The results are given in Table 3 and Figure 10. The differences show a linear relation with calcium content in rhodonite, i.e., with increasing of calcium content $\Delta \mathrm{A}$ and $\Delta \mathrm{C}$ increase and simultaneously $\Delta \mathrm{B}$ decreases. Results of indexing show that $\Delta \mathrm{A}$ is $2 \theta(200)-2 \theta(020)$, which signifies the difference between $\mathrm{a}^{*}$ and $\mathrm{b}^{*}$.

\section{Heating effect}

The chemically analyzed rhodonites were heated in air in the platinum elec- 
tric furnace. After heating for 1 hour at each temperature $\left(200-1200^{\circ} \mathrm{C}\right)$, the samples were cooled in air at once. The powder patterns of the products, particularly a range from $30^{\circ}$ to $40^{\circ}$ in $2 \theta$, were examined by the X-ray differactometer.

A. Heating up to $1000^{\circ} \mathrm{C}$

Heating was made at $200^{\circ}, 400^{\circ}, 600^{\circ}, 800^{\circ}$, and $1000^{\circ} \mathrm{C}$ respectively. The resutls are shown in Figure 11, which shows decreases of $\Delta \mathrm{A}$ and $\Delta \mathrm{C}$ and increase of $\Delta \mathrm{B}$ with rising temperature. These changes have been completed at $800^{\circ} \mathrm{C}$.
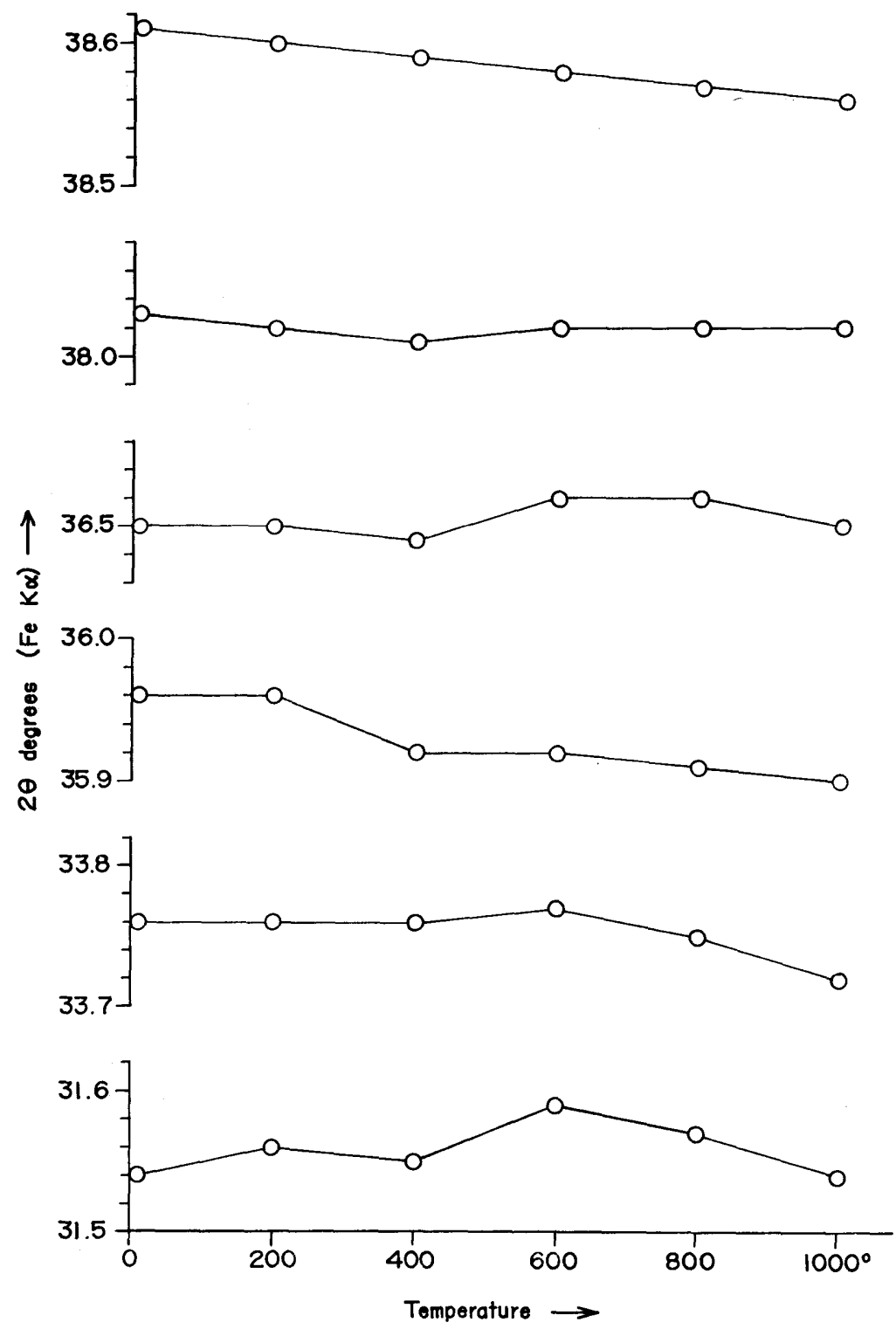

Fig. 11. Heating effect to diffraction patterns $\left(30^{\circ}-40^{\circ}\right.$ in $\left.2 \theta\right)$ of rhodonite from the Yanagaso mine, Yamaguchi Prefecture (No. 48). 


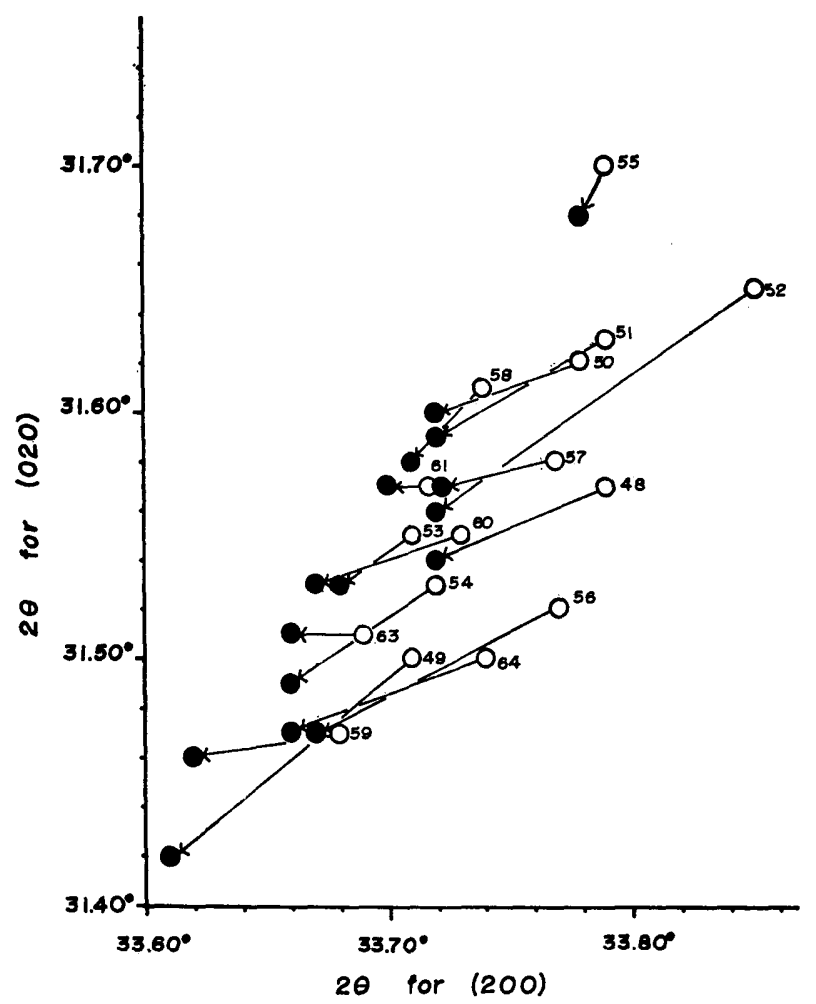

Fig. 12. Changes of the diffraction angles, $2 \theta(020)$ and $2 \theta(200)$ by heating at $1000^{\circ} \mathrm{C}$ of various rhodonites.

A large number of rhodonites from various localities were heated at $1000^{\circ} \mathrm{C}$, and the angles of (020) and (200) reflections were measured carefully. The results, shown in Figure 12, indicate the following facts: (1) the angles of (020) and (200) reflections of all rhodonites decrease by heating, which signifies decreases of $a^{*}$ and $b^{*}$; (2) the quantities of the changes are more remarkable in the iron-rich rhodonites (No. 52, Hata; No. 56, Miyasugi). The decreases of $a^{*}$ and $b^{*}$ probably signify increases of $a_{0}$ and $b_{0}$ of the unit cell, and also expansion of the cell.

The differences $\Delta \mathrm{A}, \Delta \mathrm{B}$, and $\Delta \mathrm{C}$ of the various rhodonites were also measured. The results are listed in Table 3 , and some mutual relations are shown in Figures $13,14,15$. Heating at $1000^{\circ} \mathrm{C}$ brings about decreases of $\Delta \mathrm{A}$ and $\Delta \mathrm{C}$, and increases of $\Delta \mathrm{B}$. These changes are identical to those of the Yanagaso rhodonite mentioned above. It is also described above that the differences are closely related to the content of calcium. Accordingly, three diagrams of Figures 13,14 , and 15 indicate that the extents of the changes depend on the calcium contents of rhodonites: (1) by heating, the calcium-bearing rhodonites (Nos. 48, 49,56 , and 64) become to show the similar differences $(\Delta \mathrm{A}, \Delta \mathrm{B}$, and $\Delta \mathrm{C}$ ) to those of calcium-poor ones; (2) calcium-poor rhodonites (Nos. 55, 58, and 61) show very small changes by heating. 


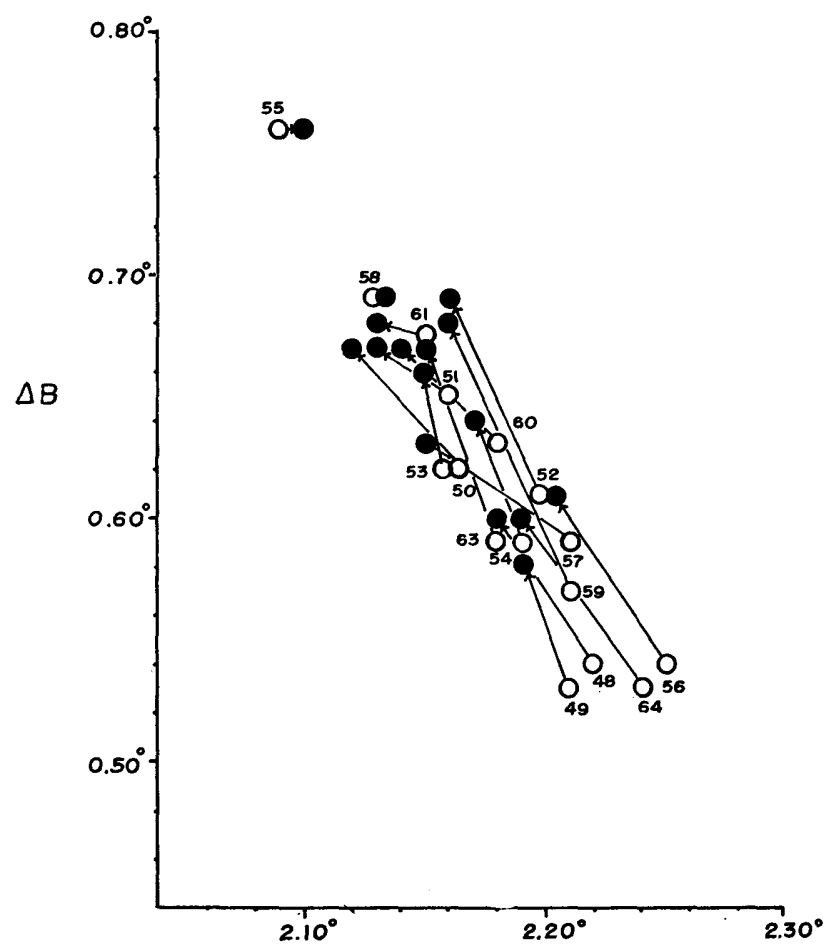

Fig. 13. Relation between the differences $\Delta \mathrm{A}$ and $\Delta \mathrm{B}$ of natural (open circles) and heated (solid circles) rhodonites.

$\Delta A$

Fig. 14. Relation between the

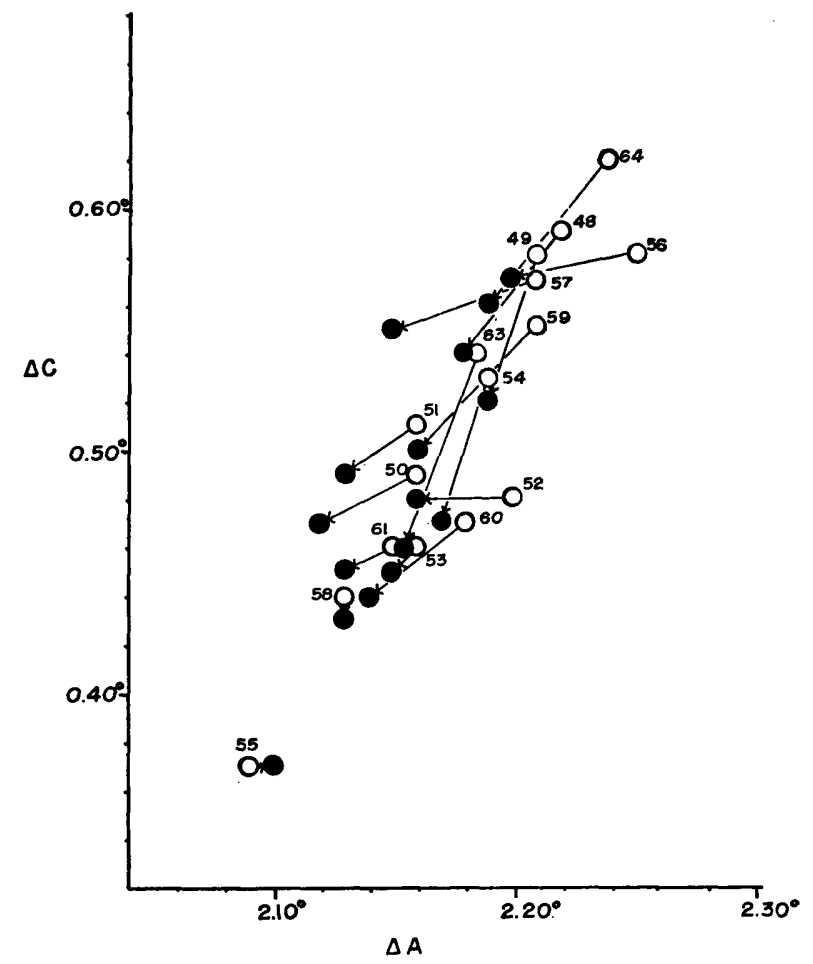
$\Delta \mathrm{A}$ and $\Delta \mathrm{C}$ of nat ural (open circles) and heated (solid circles) rhodonites. 


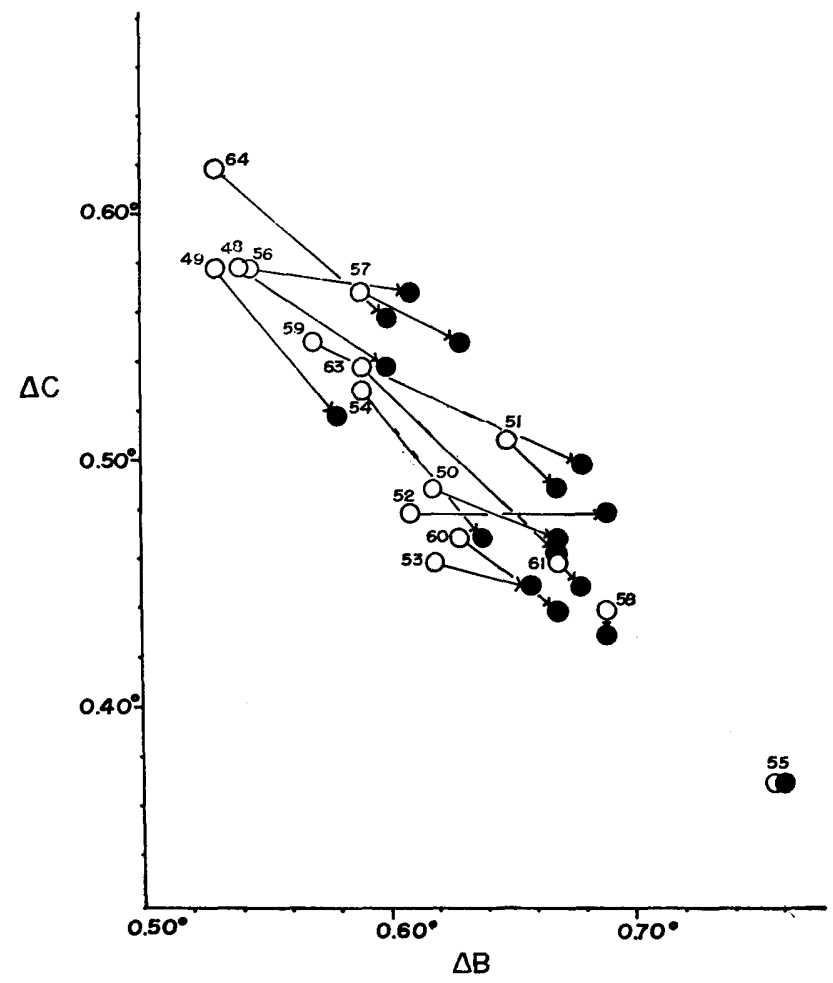

Fig. 15. Relation between the differences $\Delta \mathrm{B}$ and $\Delta \mathrm{C}$ of natural (open circles) and heated (solid circles) rhodonites.

\section{B. Heating at $1200^{\circ} \mathrm{C}$}

Transformation phenomenon of rhodonites was studied by LIEBAU et al. (1958). In their study of the system $\mathrm{MnSiO}_{3}-(\mathrm{Mn}, \mathrm{Ca}) \mathrm{SiO}_{3}$, it was clarified that synthetic rhodonite transforms to bustamite at $1160^{\circ} \mathrm{C}$. Also, Glasser and GLASSER (1962) heated a rhodonite crystal at about $1150^{\circ} \mathrm{C}$ for a few minutes and examined by the X-ray single crystal method, and deduced a mechanism involving silicon migration.

Rhodonite from Yanagaso (No. 48) was heated at $1200^{\circ} \mathrm{C}$ for 1 hour. The product, identified as bustamite, is compared with some other heated manganese silicates in Table 4 and Figure 16 . The $d$ values of their reflections decrease with increasing of manganese, i.e. the order is wollastonite, heated johannsenite (Momor, 1963), bustamite, heated inesite (Yoshimura and Momor, 1960), and heated rhodonite. The values of $\mathrm{a}^{*}$ and $\mathrm{c}^{*}$ also decrease obviously with increasing of calcium. Accordingly, the original order unchanged by heating.

\section{Some genetical considerations}

Rhodonites from various mines as well as the chemically analyzed specimens were examined with the X-ray diffractometer, and the differences $(\Delta A, \Delta B$, 


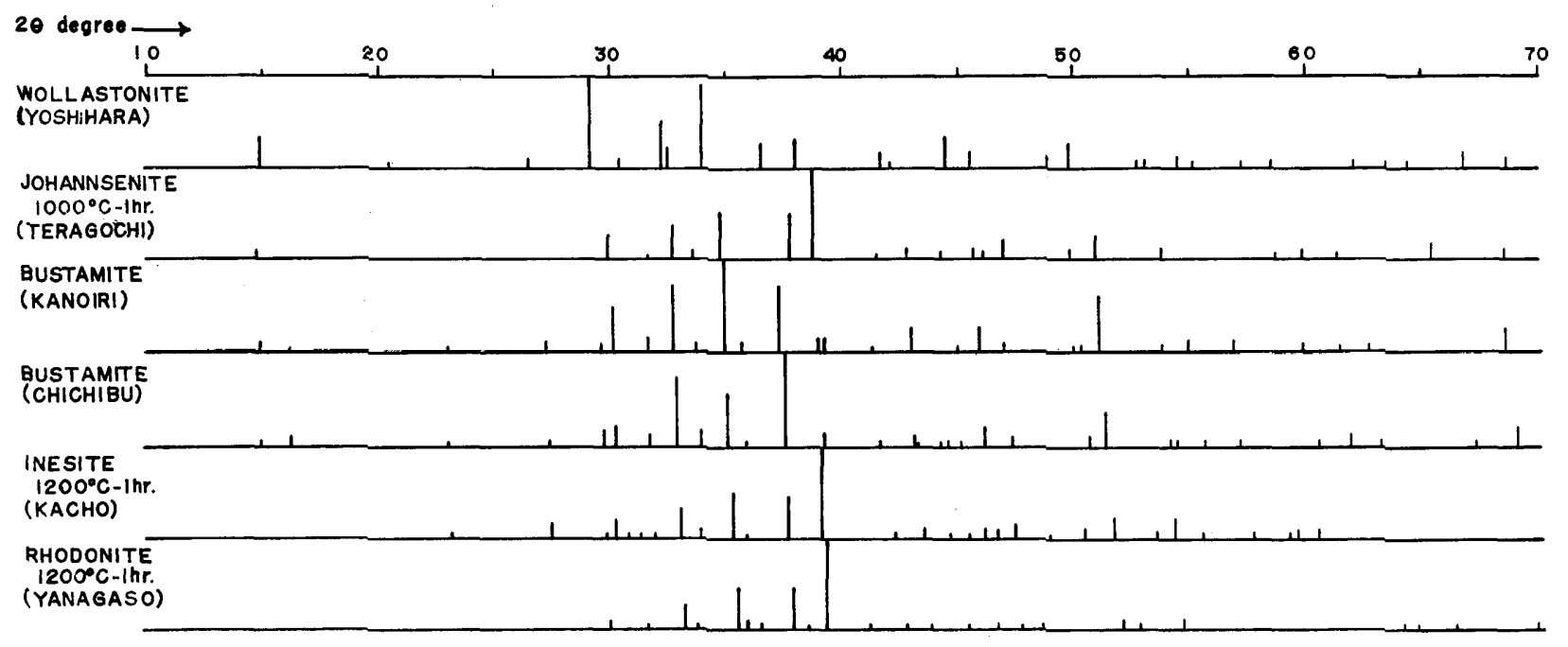

Fig. 16. X-ray powder patterns of wollastonite, bustamite, and some heated manganese silicates. 
Table 4. X-ray powder data for some heated manganese silicates, natural bustamite and wollasonite

( $\mathrm{Fe} \mathrm{K} \alpha$ radiation)

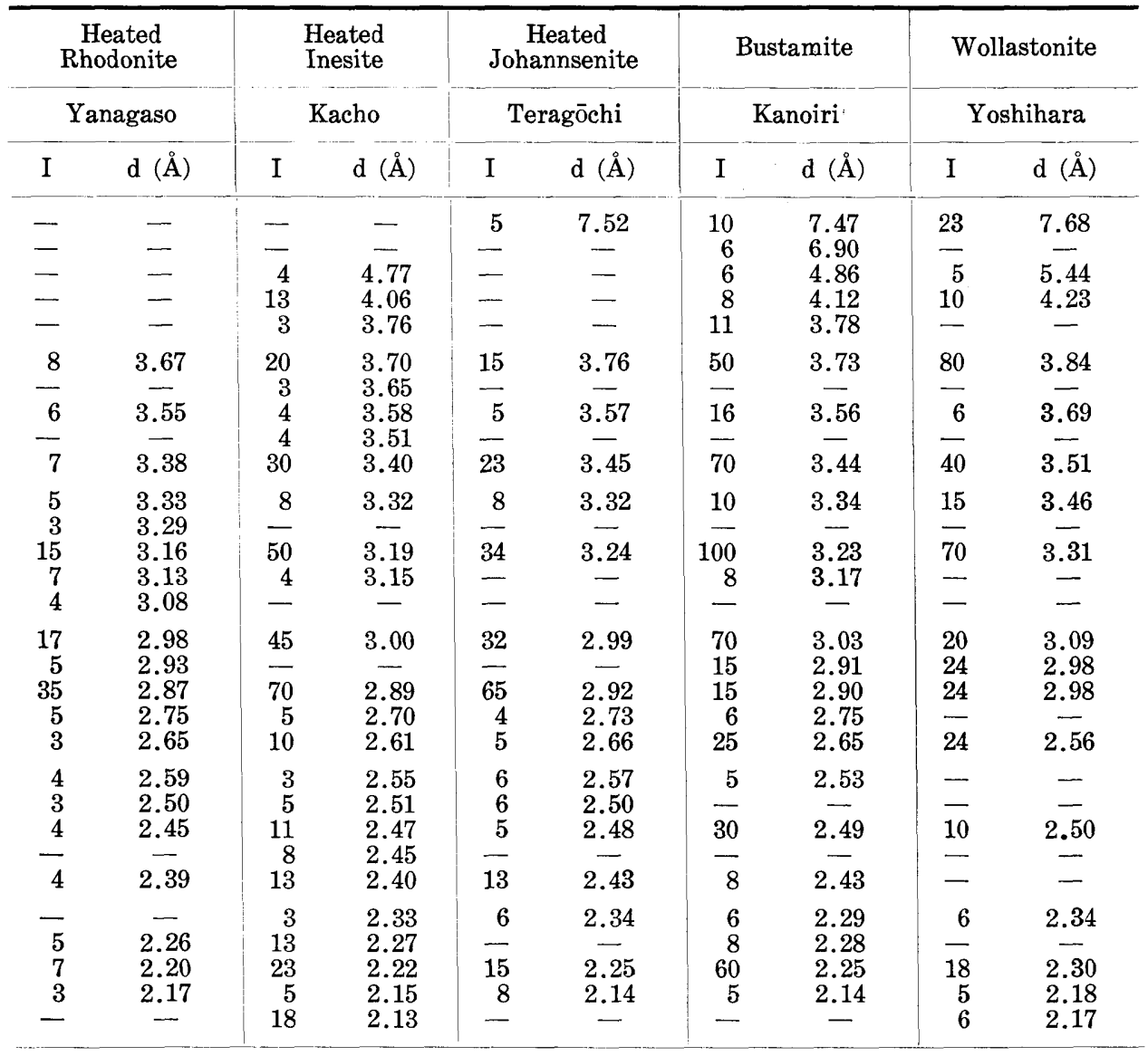

and $\Delta \mathrm{C}$ ) were carefully measured. The results, being plotted in Figure 17, are discussed here in relation to their textures and occurrences.

\section{A. Differences between metamorphic and replacement rhodonites}

Rhodonites with mosaic and hornfelsic textures have high values of $\Delta B$ and low of $\Delta \mathrm{A}$ and $\Delta \mathrm{C}$. This means that they are chemically poor in calcium. Rhodonites in replacement ores show the reverse tendency to these metamorphic Yakeno type* ore, and are plotted in the area of the calcium-bearing rhodonites. Rhodonites in the metamorphic ores are thus clearly different from those in the replacement ores.

In the replacement ores, calcite (mainly manganoan calcite) often intimately associated with rhodonite, which contains some amount of calcium and shows idiomorphic form in calcite. In the metamorphic ores, quartz is a closely

* Refer to YoshimurA's classification for Japanese manganese ore (YoshimuRA, 1952). 


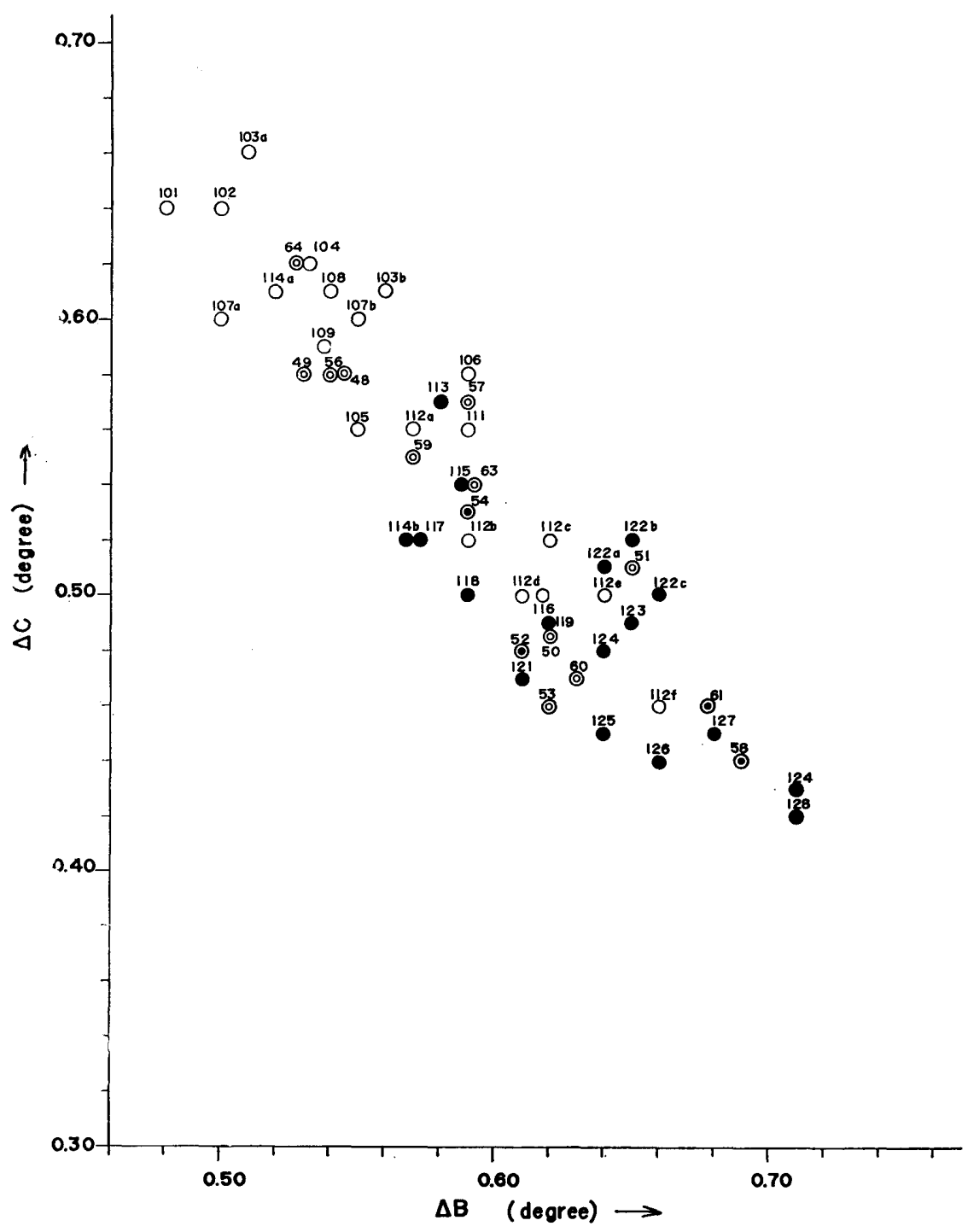

Fig. 17. Relation between $\Delta \mathrm{B}$ and $\Delta \mathrm{C}$ in $\mathrm{X}$-ray powder patterns of various rhodonites from Japan; Double circles, specimens with chemical data in this paper: open circles, replacement type: solid circles, metamorphic type.

associated mineral. Accordingly, the diagram (Fig. 17) seems also to indicate probability of the association of calcite.

From the chemical compositions of rhodonites we could infer their occurrences and parageneses. Rhodonites in the ore veins cutting limestone (No. 101) or in the limestone-contact ores are a most high calcium variety, and those of Langban, Sweden (Sundius, 1931) belong to this variety $\left(\mathrm{CaSiO}_{3}\right.$ $15-20 \mathrm{~mol} . \%)$. The second high calcium rhodonites $\left(\mathrm{CaSiO}_{3} 12-15 \mathrm{~mol} \%\right.$ ) are of vein, which is characterized by calcite, quartz, and manganese axinite, 
and is cutting bementite-braunite ore (Ananai type*). Of the rhodonite in the replacement ores, those of the Paleozoic formation (Kaso type*) fall in the middle area, mixing partially with the metamorphic rhodonites, and contain 8-12 molecular per cent of $\mathrm{CaSiO}_{3}$.

\section{B. Resemblance between metamorphic and heated rhodonite}

The plotted area of metamorphic rhodonites in Figure 17 is almost the same position to that of heated rhodonites in Figure 15. Moreover, the difference between calcium-bearing rhodonites and its heated products in Figure 15 is very similar to the difference between the metamorphic and replacement rhodonits. This suggests that change of the replacement rhodonite to the metamorphic one in thermal metamorphism, corresponds to the change of Ca-bearing one to Ca-poor rhodonite.

\section{Rhodonite in contact metamorphism}

When calcium-bearing rhodonite changes to calcium-poor rhodonite by contact metamorphism, a question that whereabouts does the calcium released from rhodonite go. There are some presumptions for an answer. (1) Since spessartine enclosed in rhodonite has anisotropic rim, and ugrandite is commonly anisotropic, this phenomenon might be a solution. (2) Except garnet, calcium-bearing mineral associating with the metamorphic rhodonite is rare, and the following presumption also is possible. Without changing total calcium content in ore, rhodonite can change into calcium-poor one as shown in the following reactions;

$$
\begin{aligned}
& \left(\mathrm{Mn}_{0.8} \mathrm{Ca}_{0.2}\right) \mathrm{SiO}_{3}+\mathrm{MnSiO}_{3} \longrightarrow 2\left(\mathrm{Mn}_{0.9} \mathrm{Ca}_{0.1}\right) \mathrm{SiO}_{3} \\
& \text { Rhodonite Pyroxmangite Ca-poor rhodonite } \\
& \left(\mathrm{Mn}_{0.8} \mathrm{Ca}_{0.2}\right) \mathrm{SiO}_{3}+\mathrm{MnCO}_{3}+\mathrm{SiO} \longrightarrow 2\left(\mathrm{Mn}_{0.9} \mathrm{Ca}_{0.1}\right) \mathrm{SiO}_{3}+\mathrm{CO}_{2} \\
& \text { Rhodonite Rhodochrosite } \quad \text { Ca-poor rhodonite }
\end{aligned}
$$

The Ca-poor rhodonite from the mineral assemblage of replacement type may be formed by thermal metamorphism according to the above formulae. In the metamorphic ore, however, these mineral associations are very rare.

On the other hand, the occurrences of the metamorphic rhodonite from Japan are very similar with each other. The deposits are commonly found in the chert beds of the Paleozoic formation (Permian age), and the environments are originally poor in calcium. However, there is no sufficient reason for that Ca-bearing rhodonite is rare in contact metamorphic aureoles. Although any explanation was made, it is the interesting fact that the rhodonite from contact metamorphic aureoles is poor in calcium. It suggests that the high temperature condition such as contact metamorphism is more suitable for the crystallization of Ca-poor rhodonite than the condition of replacement.

\section{Acknowledgments}

I express my best thanks to Professor Toyofumi Yoshimura of Kyushu University for his constant guidance and encouragement during this work, for reading the manuscript, and for giving me the privilege of studying his 
valuable collection of manganese ores. Thanks are due to Dr. Haruo SHIRozU of Kyushu University for his careful reading of the draft and for his valuable criticisms; to Dr. Fumitoshi Hrowatari of Geological Survey of Japan and to Dr. Mayumi Yoshinaga of Kyushu University at that time, for their much discussions and suggestions.

I wish also to express my particular thanks to Professor Toru Tomita of Kyushu University for reading the manuscript with constructive criticism and for his helpful suggestions, to Professor Takeo Watanabe of Tokyo University for his kindness in supplying information on the literature and in providing the specimens, to Dr. Masaru YAMAGUCHI of Kyushu University and Professor Yoshifumi KARAKIDA of Seinan University and Dr. Ikuwo OBATA of National Science Museum of Japan for their many advices.

I am indebted to the Ministry of Education for the Grant in Aid for Scientific Researches which made this study possible.

\section{Footnotes for tables and figures}

\section{Rhodonites cited from the literatures.}

1-8, Sundius (1931); 16-19, Hietanen (1936); 28-31, Yoshimura (1938); 32-33 Yoshimura (1940-41); 34-35, Harada (1933); 36, YoshimURa (1952); 37, RusSell (1946); 38, ORLov (1935); 39, Wang (1936); 40, Kodera (1955); 41, Kitahara (1948); 42, Sinitza (1957); 44, NABU (1959); 47, Yoshimura and Momol (1960); 68-69, LeE (1955); 70-71, Hill (1956).

\section{Pyroxmangites cited from the literatures.}

9, Ford (1913); 10, Henderson and Glass (1936); 11, 25-27, Sundius (1931); 12, Tilley (1937); 13-15, Hietanen (1936); 20-21, LeE (1955); 22, Masutomi and Uchiyama (1940); 23, SAKURAi et. al. (1956); 24, OMORI et. al. (1955); 43, Sinitza (1957); 46, YoshimURA et. al. (1958).

Rhodonites having new data in this paper.

48 Yanagaso adit, Kusugi mine, Yamaguchi Prefecture. Light pink colored rhodonite with large cleavage planes (ca. $5 \mathrm{~cm}$ ). Ore is replaced by pyrite-sphalerite-quartz vein. Pyrophanite, spessartine, and apatite are enclosed in rhodonite.

49 Yoshida mine, Tochigi Prefecture. Beautiful pink rhodonite with banded structure due to the alternations of different layers composed of calcite and rhodonite. The analysed sample includes the impurity of calcite, about 5 wt.\%. Original data: $\mathrm{SiO}_{2} 44.19, \mathrm{Al}_{2} \mathrm{O}_{3}$ $0.95, \mathrm{Fe}_{2} \mathrm{O}_{3}$ 0.46, $\mathrm{FeO} 0.29, \mathrm{MnO} 43.98, \mathrm{MgO} 0.41, \mathrm{CaO} 8.03, \mathrm{H}_{2} \mathrm{O}^{+} 2.35, \mathrm{H}_{2} \mathrm{O}^{-} 0.25$, total 100.64 .

50 Bandai mine, Yamaguchi Prefecture. Pink rhodonite associated with dannemorite and spessartine showing banded structure due to quartz-rhodonite and carbonaceous matterspessartine-dannemorite layers.

51 Inotani adit, Kusugi mine, Yamaguchi Prefecture. Spessartine-rhodonite ore with mosaic texture is replaced by quartz-dannemorite veins.

52 Hata mine, Yamaguchi Prefecture. Ore composed of rhodonite and spessartine with pyrophanite inclusions has mosaic texture.

53 Chizu mine, Tottori Prefecture. Pink rhodonite with sutured mosaic texture, and replaced by quartz vein.

54 Horigoshi mine, Okayama Prefecture. Pink rhodonite ore with mosaic texture.

55 Taguchi mine, Aichi Prefecture. Reddish rhodonite of vein-like form in tephroite show 
mosaic texture.

56 Miyasugi adit, Kusugi mine, Yamaguchi Prefecture. Pink rhodonite with small amounts of red pyrophanite and spessartine.

57 Renge mine, Yamaguchi Prefecture. Pink rhodonite with large cleavage planes (ca. $3 \mathrm{~cm}$ ) impregnated with pyrite-sphalerite-quartz veins.

58 Zōmeki adit, Kusugi mine, Yamaguchi Prefecture. Pink rhodonite with poikilitic texture due to tephroite inclusions. Specimen is carbonitized, associated with spessartine and pyrophanite.

59 Akimoto mine, Miyazaki Prefecture. Calcite-rhodonite vein in bementite ore.

60 Tamaiwa mine, Kyoto Prefecture. Rhodonite aggregates surrounded by fine carbonate (?), having a ball-like appearance (ca. $1 \mathrm{~mm}$ in diameter).

61 Hijiritani adit, Kiura mine, Oita Prefecture. Mosaic aggregates of purplish rhodonite with common inclusions of pyrophanites enclosed in fine-grained pink rhodonites. Purplish portion was analysed. Other oxide: $\mathrm{BaO} 1.14 \%$.

63 Yamato mine, Kagoshima Prefecture. Purplish rhodonite aggregates with barite and rhodochrosite veinlets. Other oxides: $\mathrm{BaO} 2.23, \mathrm{SO}_{3} 1.06 \%$.

64 Hsihutsun, north of Peiping, North China. Purplish red rhodonite aggregates. The specimen is labelled " hsihutsunite" in YoshImURA's collection.

101 Chichibu mine, Saitama Prefecture. Brownish-pink rhodonite in direct contact with saccharoidal limestone.

102 Banba mine, Saitama Prefecture. Calcite-mangan axinite-rhodonite ore.

103 Ananai mine, Kochi Prefecture. (a) Fibrous brown rhodonite with calcite; (b) Calcitemanganese axinite-rhodonite ore.

104 Ōkuki mine, Ehime Prefecture. Rhodonite-quartz vein cross-cutting greenish yellow garnet rock in the upper red chert which is in the hanging wall of "Kieslarger."

105 Kunimiyama mine, Kōchi Prefecture. Fibrous pink rhodonite in calcite vein cutting the iron-manganess ore.

106 Kaso mine, Tochigi Prefecture. Beautiful pink rhodonite in chlorite vein.

107 Ōtaki mine, Nagano Prefecture. (a) Pink rhodonite with dannemorite and spessartine; (b) Rhodonite colored black with impregnated manganese oxide.

108 Kurohime mine, Shizuoka Prefecture. Pink rhodonite replaced by bementite.

109 Fujii mine, Fukui Prefecture. Tephroite-red rhodonite ore partially showing opal-like feature.

111 Sanpo mine, Ehime Prefecture. Tephroite-rhodonite ore cut by feldspar veins.

112 Tenno mine, Yamaguchi Prefecture. (a) Spessartine-rhodonite ore replaced by pyritesphalerite-quartz veins; (b) Tephroite-alabandite-rhodonite ore; (c) Alabandite-tephroiterhodonite ore; (d) Tephroite-spessartine-pyroxmangite-rhodonite ore; (e) Tephroite-rhodonite; (f) Alabandite-tephroite-penwithite-rhodonite ore.

113 Tanohata mine, Iwate Prefecture. Quartz-feldspar-richterite-rhodonite ore with granoblastic texture.

114 Hijiritani adit, Kiura mine, Ōita Prefecture. (a) Purplish opal-like rhodonite; (b) Fine mosaic pink rhodonite, enclosing purple rhodonite aggregates (No. 61).

115 Hata mine, Yamaguchi Prefecture. Quartz-spessartine-rhodonite ore with mosaic texture, cut by pegmatitic veins.

116 Yamato mine, Kagoshima Prefecture. Alkali feldspar-pink rhodonite ore replacing braunite ore.

117 Tashiro mine, Yamaguchi Prefecture. Spessartine-rhodonite ore with rhodochrosite patches with mosaic texture in part.

118 Waki mine, Yamaguchi Prefecture. Alabandite-tephroite-rhodonite ore with mosaic texture.

119 Furuzyuku mine, Yamaguchi Prefecture. Galaxite-alabandite-rhodochrosite-quartz ore with hornfels texture.

120 Hokoku mine, Ehime Prefecture. Saccharoidal pink rhodonite surrounded by manganese oxide. 
122 Nodatamagawa mine, Iwate Prefecture. (a) Mosaic rhodonite ore with lenticular penwithite; (b) Coarse grained pink rhodonite; (c) Feldspar-tephroite-red rhodonite ore with mosaic texture.

123 Minenosawa adit, Kune mine, Shizuoka Prefecture. Rhodochrosite-rhodonite lense in magnetite-quartz schist.

124 Taguchi mine, Aichi Prefecture. (a) Biotite-tephroite-rhodonite ore with mosaic texture; (b) Aggregates of tephroite and rhodonite surrounded by rhodochrosite.

125 Ushiiwa adit, Kusugi mine, Yamaguchi Prefecture. Spessartine-rhodonite banded ore by dannemorite-quartz veinlets. As a whole, carbonitization is dominant.

127 Ioi mine, Shiga Prefecture. Tephroite-spessartine-rhodonite ore. Pinkish-red rhodonite encloses red and yellow pyrophanites.

128 Zomeki adit, Kusugi mine, Yamaguchi Prefecture. Reddish-pink rhodonite enclosed in alabandite ore.

Pyroxmangites having new data in this paper.

62 Taguchi mine, Aichi Prefecture. Purple pyroxmangite showing mosaic texture associated with spessartine and dannemorite. Chemical composition; $\mathrm{FeO} 5.69, \mathrm{MnO} 45.02, \mathrm{MgO}$ 3.13 , and $\mathrm{CaO} 0.93$ wt.\%. Refractive indices; $\mathrm{Nx} 1.730, \mathrm{Ny} 1.732, \mathrm{Nz} 1.748$, and $\mathrm{Nz}-\mathrm{Nx}$ 0.018 .

63 Takamori mine, Yamaguchi Prefecture. Red pyroxmangite associated with alabandite and rhodochrosite. It is beautiful idiomorphic crystal. Chemical composition; FeO 1.39, $\mathrm{MnO}$ 51.10, $\mathrm{MgO} 1.46$, and $\mathrm{CaO} 0.92$ wt.\%. Refractive indices; $\mathrm{Nx} 1.730, \mathrm{Ny} 1.733, \mathrm{Nz} 1.748$, and $\mathrm{Nz}-\mathrm{Nx}$ 0.018. 2Vz 46.0. Sp. gr. 3.73.

64 Kiyotaki mine, Nagano prefecture. Red pyroxmangite accompanied by spessartine and tephroite. Chemical composition; $\mathrm{Fe}_{2} \mathrm{O}_{3} 0.96, \mathrm{MnO} 51.91, \mathrm{MgO} 0.83$, and $\mathrm{CaO} 0.32$ wt.\%. Refractive indices; $\mathrm{Nx}$ 1.735, $\mathrm{Ny}$ 1.738, Nz 1.755, and Nz-Nx 0.020. Sp. gr. 3.65.

\section{References}

BUERgER, M. J. (1956): The arrangement of atoms in crystals of the wollastonite group of metasilicates. Proc. Nat. Acad. Sci. U.S. A., 42, 113-116.

Buerger, M. J. and PrewitT, C. T. (1961): The crystal structures of wollastonite and pectolite. Proc. Nat. Acad. Sci., 47, 1884-1888.

Ford, W. E. and BRAdley, W. M. (1913): Pyroxmangite, a new member of pyroxene group and it alteration product, skemmatite. Am. Jour. Sci., 186, 169-174.

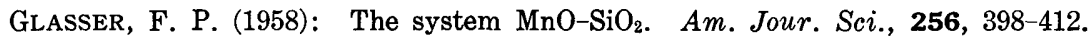

- (1960): Results of phase equilibrium investigations in the systems $\mathrm{MgO}-\mathrm{MnO}_{-} \mathrm{SiO}_{2}$ and $\mathrm{CaO}-\mathrm{MnO}-\mathrm{SiO}_{2}$. Silikat. Tech., 11, 362-363.

Glasser, L. S. D. and Glasser, F. P. (1961): Silicate transformation: Rhodonite- wollastonite. Acta Cryst., 14, 818-822.

HARAdA, Jumpei (1933): Some minerals of Japan. (2) Rhodonite (in Japanese). Jour. Geol. Soc. Japan, 40, 342-343.

Henderson, E. P. and Glass, J. J. (1936): Pyroxmangite, new locality: Identity of sobralite and pyroxmangite. Am. Mineral., 21, 273-294.

HEY, M. H. (1929): The variation of optical properties with chemical composition in rhodonitebustamite series. Mineral. Mag., 22, 193-205.

Hietanen, Anna. (1936): Uber den Rhodonit und andere Manganminerale von Simsio Pahjanmae. Bull. Comm. Geol. Finlande, 115, 387-400.

HILl, F. W. (1956): Optische, thermooptische und chemische Untersuchungen an Rhodoniten. Hamburber Beitrage zur Angewandten Mineralogie und Kristallphysik, Festschrift zum 70 Geburstag Hermann Rose's, 1 Folge, 138-182.

Hutton, C. O. (1956): Manganpyrosmalite, bustamite, and ferroan johannsenite from Broken Hill, New South Wales, Australia. Am. Mineral., 41, 581-591. 
KitAHARA, Juniche (1948): Mineralization of manganese in the Hamayokogawa mine, Nagano Prefecture (in Japanese). Jour. Geol. Soc. Japan, 54, 181-183.

Kodera, Miroslav (1955): Rhodonite from Banska Stiavnica (in Czechoslovak with German Summary). Geol. Sbornik, 6, 227-231.

LEE, D. E. (1955): Mineralogy of some Japanese manganese ores. Stanford Univ. Publ., Univ. Ser., Geology, 5, 1-64.

Liebau, F., Sprung, N. and Thilo, E. (1958): Uber das System $\mathrm{MnSiO}_{3}-\mathrm{CaMn}\left(\mathrm{SiO}_{3}\right)_{2}$. Zeit. anorg. $u$. allgem. Chem., 297, 213-225.

Liebau, Friedrich. (1959): Über die Kristallstruktur des Pyroxmangit (Mn, Fe, $\mathrm{Ca}, \mathrm{Mg}$ ) $\mathrm{SiO}_{3}$. Acta Cryst., 12, 177-181.

Liebau, Friedrich, Hilmers, Waltrud, and LindemanN, Gerhard (1959): Uuber die Kristallstruktur des Rhodonit (Mn, Ca) $\mathrm{SiO}_{3}$. Acta Cryst., 12, 182-187.

Masutomi, Junosuke and Uchiyama, Heihachiro (1940): Minerals of Kyoto Prefecture (in Japanese). 240 pp. Kyoto.

Momor, Hitoshi (1964): Johannsenite from Teragochi, Okayama Prefecture, Japan. Mem. Fac. Sci., Kyushu Univ., Ser. D, Geology, 15, (1), 65-72.

MUAN, Arnulf (1959): Phase equilibriums in the system manganese oxide-sillcon dioxide-air. Am. Jour. Sci., 257, 297-315.

NANBU, Matsuo (1959): Some manganese ores in Kitakami mountainland (in Japanese). Publ. Iwate Prefecture. $33 \mathrm{pp}$.

ORLov, Alexandr (1935): Rhodonite from Morasice, Iron Mountaines. Casopis Narodniho Musea, Praha, 109, 5-7.

OMORI, Keiichi and Hasegawa, Shūzo (1955): Chemical compositions of perthite, ilmenite, allanite and pyroxmangite occurred in pegmatites of vicinity of Iwaizumi Town, Iwate Prefecture (in Japanese). Jour. Jap. Assoc. Mineral. Petrol. Econ. Geol., 39, 91-98.

Peacor, D. R. and Buerger, M. J. (1962): Determination and refinement of the crystal structure of bustamite, $\mathrm{CaMnSi}_{2} \mathrm{O}_{6}$. Zeit, Krist., 117, 331-343.

Russell, Arthur (1946): On rhodonite and tephroite from Treburland manganese mine, Altertun, Cornwall, and on rhodonite from other localities in Cornwall and Devonshire. Mineral. Mag., 27, 221-235.

SakuraI, Kinichi, NAgashima, Kozo and TAKasu, Shinichiro (1959): Pyroxmangite from Kamiotomo, Iwate Prefecture (in Japanese). Jour. Mineral. Soc. Japan., 2, 407-412.

SinitzA, S. (1957): Mineralogy of the manganese ores of the Preluzhnyi Ridge in the Cihvchinsk Mountains. Mineral. Sornik, L'vov. Gesudarst. Univ. im. I. Franko $195 \%$. No. $11,170-186$.

SundiUs, Nils. (1931): On the triclinic manganiferous pyroxenes. Am. Mineral., 16, 411$429 ; 488-518$.

Tilley, C. E. (1937): Pyroxmangite from Inverness-Shire, Scotland. Mineral. Mag., 22, 720727.

WANG, C. C. (1936): The rhodonite veins of Hsihutsun, Changping district, north Peiping. Bull. Geol. Soc. China, 15, 87-104.

Yoshimura, Toyofumi (1938): Geology and ore deposits of Kaso mine, Tochigi Prefecture, with special reference to mineral paragenesis (in Japanese). Jour. Geol. Soc. Japan, 45, 91-204.

, (1940-41): Geology and ore deposits of the Yamato mine, Kagoshima Prefecture (in Japanese). Jap. Assoc. Mineral. Petrol. Econ. Geol., 24, 235-244; 25, 21-29.

-..., (1952): Manganese deposits in Japan (in Japanese). Manganese Investigation Association, 567 pp.

Yoshimura, Toyofumi, Shirozu, Haruo and Hirowatari, Fumitoshi (1958): Bementite and pyroxmangite from the Ichinomata mine, Kumamoto Prefecture (in Japanese). Jour. Mineral. Soc. Japan, 3, 457-467.

Yoshimura, Toyofumi and MomoI, Hitoshi (1960): Inesite from the Kacho mine, Kochi Prefecture, Japan (in Japanese). Jour. Mineral. Soc. Japan, 5, (5), 1-10. 